
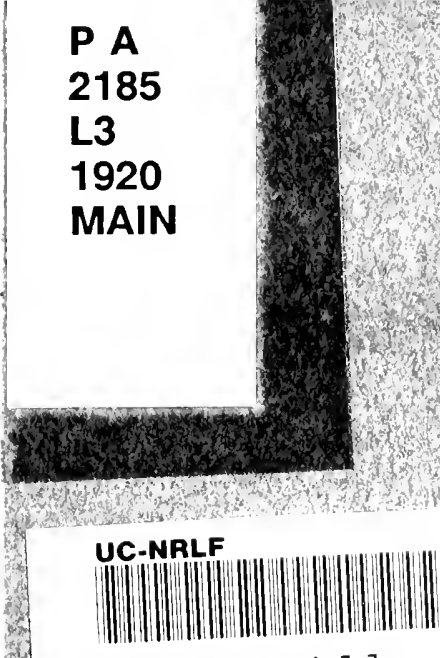

B 4 a 38 bl
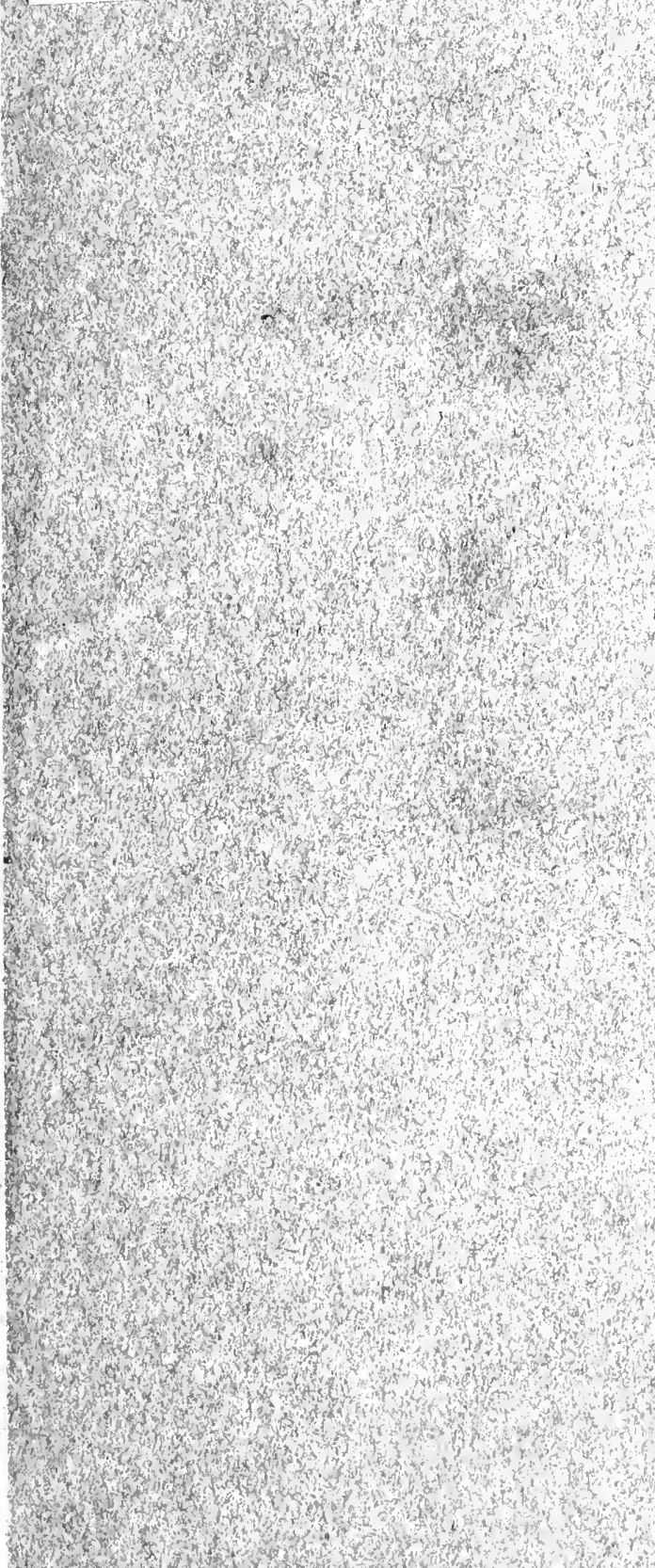


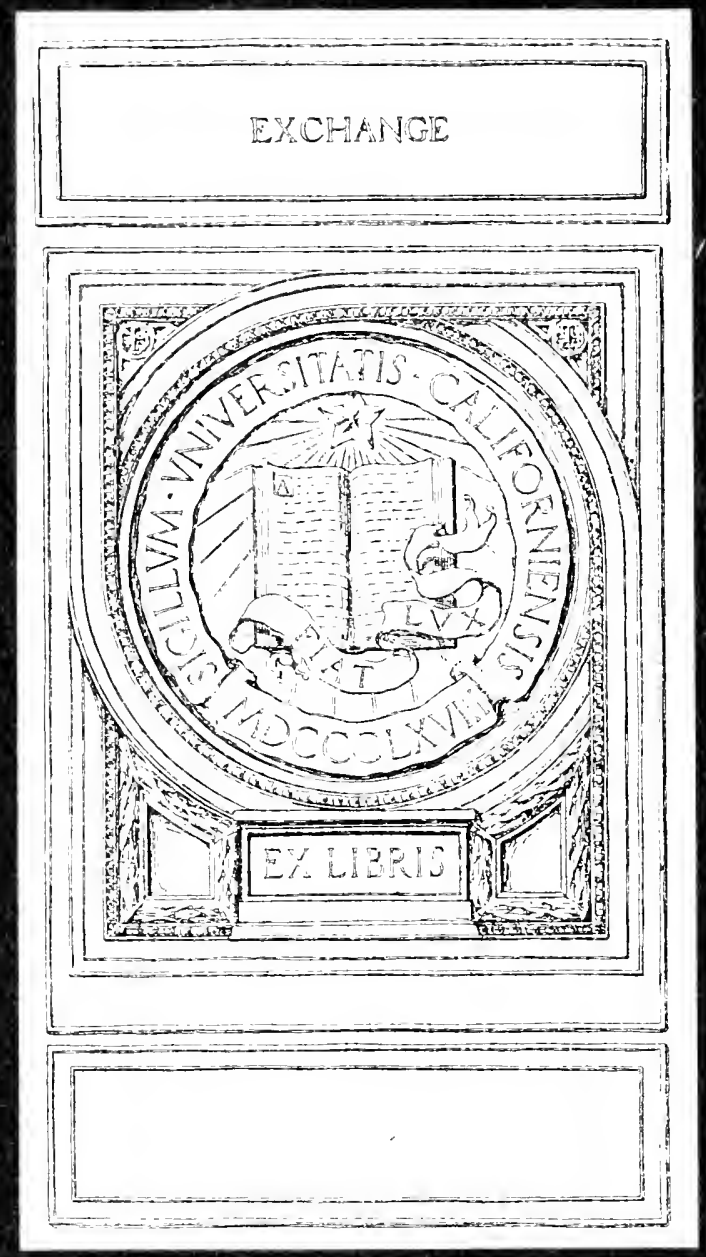




\title{
The Genitive of Value in Latin and Other Constructions with Verbs of Rating
}

\author{
DISSERTATION \\ SUBMITTED TO THE BOARD OF UNIVERSITY STUDIES OF THE JOHNS HOPKINS \\ UNIVERSITY IN CONFORMITY WITH THE REQUIREMENTS FOR \\ THE DEGREE OF DOCTOR OF PHILOSOPHY
}

\author{
BY \\ GORDON J. LAING
}

THE LIBRARY OF THE JOHNS HOPKINS UNIVERSITY

BALTIMORE, MARYLAND 


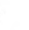




\section{The Genitive of Value in Latin and Other Constructions with Verbs of Rating}

\section{DISSERTATION}

SUBMITTED TO THE BOARD OF UNIVERSITY STUDIES OF THE JOHNS HOPKINS UNIVERSITY IN CONFORMITY WITH THE REQUIREMENTS FOR THE DEGREE OF DOCTOR OF PHILOSOPHY 
COPYright I920 BY

Gordon J. LAING

All Rights Reserved

Published June I920 


\section{PREFACE}

My purpose in this monograph is twofold: (I) to determine the origin of the genitive of value and (2) to ascertain the limits of the different combinations: what genitives and ablatives are used in expressions of valuation and with what verbs they are combined; and to what extent genitives, ablatives, and verbs vary in different authors and different spheres. Throughout the paper I have endeavored to show as clearly as possible the historical development of the individual expressions and of the construction as a whole. In my treatment of the expressions of worthlessness (nihili, flocci, etc.) I have departed from the strictly syntactical phase of the subject and added such material as is available on the origin of the words or phrases. The sections on "boni consulere," "aequi bonique facere," "nihil pensi esse," and "pro nihilo" have been reprinted by permission from my article in Studies in Honor of Basil L. Gildersleeve (Johns Hopkins Press, Baltimore).

Only constructions with verbs of rating have been included in the plan of the work. Accordingly the use of the genitive with refert and interest has not been treated; nor is there any discussion of the constructions with verbs of buying and selling (the ablative and genitive of price).

The following are the authors whose works I have examined. In addition my lists have been largely supplemented by examples collected from indices and other sources. I specify titles of works only where my examination of the author has not been complete: Plautus, Terence, Fragments of the Comic and Tragic Poets (Ribbeck), Cato, Fragments of Lucilius (Marx), Cicero, Caesar, Sallust, Catullus, Varro (Satirae Menippeae), Livy, Virgil, Horace, Ovid, Tibullus, Propertius, Priapea, Persius, Phaedrus, Petronius, Seneca the Philosopher, Martial, Juvenal, Pliny the Younger, Tacitus, Fronto, Apuleius, and Gellius. With a view to determining the later usage I have also examined considerable parts of Tertullian, Arnobius, Lactantius, Firmicus Maternus, Lucifer of Cagliari, Ausonius, Symmachus, Augustine, Sulpicius Severus, Orosius, Salvianus, Eugippius, Apollinaris Sidonius, and Gregory of Tours.

G. J. L. 


$$
\text { . }
$$




\section{CONTENTS}

I. The Genitive of Value:

I. The Origin of the Construction:

a) The Theory of Locative Origin

b) The Theory of Partitive Origin

c) The Theory that the Genitive of Value Is a Variety of the Genitive of Quality

d) Wackernagel's Explanation

e) Conclusion: The Genitive of Value an Original Adverbial Construction: One of Several Instances of the Free Use of the Genitive with Verbs Expressing Various Phases of Connection or Relation. Influence of the Genitive of Quality

2. The Genitive in Indefinite Valuation:

a) (I) Magni, (2) maioris, (3) maximi, (4) multi, (5) pluris, (6) plurimi, (7) parvi, (8) minoris, (9) minimi, (10) tantiquanti, (I I) tanti, (I 2) quanti

b) (I) Boni consulere, (2) aequi bonique facere, (3) nihil pensi esse to

c) Magni preti, mullius momenti, etc. . . . . . . 23

3. The Genitive in Definite Valuation:

a) In Money Valuations . . . . . . . . . . 23

b) Simpli, dupli . . . . . . . . . . . . . . . 23

4. The Genitive in Expressions of Worthlessness:

a) (1) Nihili, (2) nulli, (3) flocci, (4) nauci, (5) hettae, (6) pili . 24

b) Coins: (I) sescunciae, (2) sextantis, (3) terunci, (4) semissis, (5) assis, (6) dupondii, (7) tressis, (8) trioboli . . . . . 29

c) Huius, accompanied by gesture . . . . . . . 30

II. The Ablative with Verbs of Rating:

I. The Origin of the Construction .

2. The Ablative in Definite Valuation:

a) In Money Valuations

b) Duplo

3. The Ablative in Indefinite Valuation:

a) (1) Pretio, (2) aere, (3) summa, (4) momento, (5) vita, (6) contubernio

b) (I) Magno, (2) maiore, (3) plure, (4) parvo, (5) minore, (6) minimo, (7) quanto-tanto, (8) quanto, (9) guantocumque, (Io) vili and caro, (I I) vilissimo 
4. The Ablative in Expressions of Worthlessness:

a) (г) Nihilo, (2) nauco . . . . . . . . . . . . . 35

b) Coins: (I) asse, (2) sestertio nummo . . . . . . . 36

5. The Ablative with a Preposition:

a) Pro: (I) In Expressions of Worthlessness (a) pro nihilo, (b) pro nullo, (c) pro luto. (2) In Indefinite Valuation (a) pro pretio, (b) pro magno aere, (c) pro magno. (3) In Definite Valuation (a) In Money Valuation, (b) pro oculo, pro dente . 37

b) In: (1) in pretio, (2) in lucro, in damno, (3) in pondere . 40

c) $\mathrm{C} u \mathrm{~m}$. . . . . . . . . . . . . 40

III. Adverbs with Verbs of Rating:

Care, carius; graviter, gravius; humiliter; iuxta; levius; multum; nihil; nimis; pensius; plus; tenuissime; vilius . . . . $4 \mathrm{I}$

IV. The Verbs of Rating:

Aestimare, censere, computare, consulere, dedicare, deprehendere, ducere, esse, existimare, facere, finire, habere, indicare, licere, pendere, pensitare, ponderare, putare, reputare, sumere, supputare, taxare, valere 


\section{THE GENITIVE OF VALUE}

\section{THE ORIGIN OF THE CONSTRUCTION}

A number of explanations of the origin of the genitive of value have been offered by grammarians. One theory is that the form is locative. According to another explanation, it is a development of the partitive genitive. The advocates of a third view see in it a variety of the genitive of quality. Finally, more recent writers have explained it on the analogy of that usage in Sanskrit by which certain genitive forms in $-i$ are combined like a verbal prefix with $k r_{-}$, "make," and $b h \bar{u}-$, "become."

a) The Theory of Locative Origin

This is the explanation given by Roby. ${ }^{\mathrm{x}}$ He regards magni, tanti, etc., as locatives which express the amount at which, and thinks that the genitives pluris, minoris, etc., are used by analogy in the same sense. This view is held by Sloman ${ }^{2}$ also. Sonnenschein in his New Latin Grammar ${ }^{3}$ says nothing about the origin, but in his Greek Grammar adopts the locative theory. None of these writers, however, advances any arguments in support of his view, and the theory is so inadequate in the case of many examples of the construction that it may be dismissed without further discussion. On one point, however, I believe it to be sound: it recognizes the original adverbial character of the construction.

\section{b) The Theory of Partitive Origin}

The explanation that the origin is to be found in the partitive genitive is given by Reisig:5 "Derselbe Teilbegriff findet statt bei den Wörtern des Schätzens mit einem Genetiv des Wertes: aestimare, facere, ducere, pendere, habere, esse. . . . . Den allgemeinen Begriff fasst man als eine Idee, welche die Mannigfaltigkeit der Wirklichkeit in sich begreift, wozu das Einzelne gehört; parvi ducere aliquid ist etwas für einen Teil halten von alledem was gering ist, daher gering achten. So auch magni, maximi, pluris, plurimi, minoris, minimi." This theory is not without plausibility, and for one of the genitives regularly included

${ }^{1}$ Grammar of the Latin Language, II, I I86-87.

${ }^{2}$ Grammar of Classical Latin (Cambridge, 1906), p. 261.

3 Oxford, I9I 2.

${ }^{4}$ London, I903.

5 Vorlesungen, III, 572 . 
under this category (pensi) it undoubtedly furnishes the correct explanation. In this case we are fortunate enough to have examples of the different stages of development: nec tantillum pensi esse (Plautus), nihil pensi habere (Caecilius Balbus), neque quicquam pensi habere (Sallust), and finally nec pensi ducere (Valerius Maximus). The same explanation may be applied to the other members of this group, namely boni (with consulere) and aequi bonique (with facere). But it is less convincing when applied to such expressions as magni, maximi, etc.; is distinctly inadequate as an explanation of flocci, nauci, etc.; and fails entirely in the case of definite valuations like emat denario quod sit mille denarium (Cicero). In brief, it is only by the most severe procrustean methods that these expressions, universally recognized as integral parts of the category of valuation, can be made to conform to the partitive idea.

c) The Theory that the Genitive of Value Is a Variety of the Genitive of Quality

The view that has been most frequently expressed and most widely accepted is that in the genitive of value we have nothing more than an extension of the genitive of quality. According to this theory the first stage may be seen in such an expression as res magni preti, which develops into res est magni preti and then into a free use of the genitive of the adjective (without preti) with facere, pendere, and other verbs of rating. This is the view held by Landgraf, ${ }^{6}$ who, after quoting Plaut. Aul. 790 mullust tam parvi preti and Trin. 257 quam preti sit parvi, remarks: "Diese beiden letzen Beispiele zeigen uns deutlich dass der sog. Genetivus preti nichts ist als ein prädikativer Gen. qualitatis, wobei im Laufe der Zeit der Genetiv des Substantivums pretium der Kürze halber gewöhnlich wegfiel." Cf. also Wölfflin, ${ }^{7}$ who says: "Der erstere [i.e., the genitive of value] ist eine Abart des Genetivus qualitatis, wie man längst erkannt hat." Along the same lines is the statement of Schmalz: "Aus hominem non nauci (Attribut) entwickelte sich sumus non nauci und dann non nauci habere." Kühner" is of the same opinion: "Dieser Gebrauch des Genetivs schliesst sich unmittelbar an den in Nr. 4 [i.e., the genitive of quality] behandelten an; er ist nur eine besondere Art desselben." This statement is repeated by Stegmann ${ }^{10}$ in his revision of Kühner's work. Dräger ${ }^{11}$ does not discuss the origin of the construc-

${ }^{6}$ Literaturnachweise und Bemerkungen (Bamberg, I894), p. 66.

7 Archiv für lateinische Lexikographic und Grammatik, IX, 102.

${ }^{8}$ Müller's Handbuch, II, $2^{4}$ (1910), p. 368.

9 Ausfülrliche Grammatik der lateinischen Sprache, II, 335.

to II, I (I912), p. 458. $\quad$ "Historische Syntax der lateinischen Sprache. 
tion, but the fact that he classifies the examples immediately after those of the genitive of quality seems to indicate that he regards the former as a development of the latter. Cf. also Madvig, ${ }^{12}$ Allen and Greenough, ${ }^{\mathrm{J3}}$ Gildersleeve-Lodge, ${ }^{14}$ Bennett, ${ }^{15}$ and Burton. ${ }^{16}$ Harkness, Lane, West, and Hale do not refer to the question of origin.

The case made out for this theory is plausible, but when tested proves unsatisfactory. The claim that the use of the genitives magni, parvi, tanti, quanti, pluris, minoris, etc., with facere, pendere, aestimare, and other verbs of rating is due to a dropping out of preti, as Landgraf suggests, is not supported by adequate evidence. Certainly the stages of this truncation cannot be traced in the Latin literature that has come down to us. The use of the genitive of the adjective (without preti or other substantive) is found fully developed in Plautus, as the examples given in the following pages abundantly show. To be sure, the combination with preti also occurs in Plautus (parvi, minimi, quantivis preti, with esse only), but instead of showing a decrease in the subsequent literature, it and similar combinations (like that with momenti) more than hold their own, giving signs even of a slight growth in the direction of an enlarged vocabulary. That this is so may be seen from an examination of the following list, which includes all the examples with verbs of rating observed in the literature examined:

Plautus: parvi preti esse (Trin. 257), minimi preti esse (Epid. 502; Mil. 558), quantivis preti esse (Pers. 622).

Terence: parvi preti esse (Hec. 799), quantivis preti esse (Andr. 856).

Cicero: parvi.preti esse (Quint.fr.i. 2. I4), alicuius preti esse (Verr.iv. 4. 8; 32), maximi momenti et ponderis esse (Vatin. 4. 9), nullius momenti putari (I. I).

Sallust: preti minimi esse (Orat. ad Caes. 2. 9).

Nepos: nullius momenti esse (Alcib. 8. 4).

Livy: parvi momenti esse (xl. 21. 2), levioris momenti esse (xxiv. 28. 5), magni momenti esse (xxii. 25. I4; xxxiii. 45.4 ; xxxvi. 9. 15), non ullius momenti esse (xxxv. 45. 8), maximi momenti haberi (xlii. 45. 3).

Columella: nullius momenti ducere (i. praef. I 2 ).

Seneca: eiusdem pretii esse (Ep. 7 I. 20).

Pliny the Elder: quanti momenti esse (H.N. xxxv. I5. 190).

Suetonius: non ullius momenti esse (Domit. Io).

12 American edition by Thacher, I902.

${ }_{13}$ Boston, 1903. $\quad{ }_{14} \mathrm{New}$ York, 1907.

Is Boston, 1907. In his Syntax of Early Latin, however, he adopts a different view. See p. 7 .

${ }^{86}$ New York, r9ir. 
Gellius: tanti momenti esse (xvi. I4. 4 ; cf. xvii. 6. 2).

Festus: nullius pretii esse (Th. de P. I70).

Arnobius: nullius pretii esse (Adv. nat. vii. 34 ), cuius pretii esse (ii. 20), nullius mominis esse (ii. $35 ; 49$ ), ponderis nullius esse (iv. I 8 ), gravioris ponderis esse (iv. 34).

Lucifer: nullius momenti facere (De reg. apost. 2).

Latin Translation of Irenaeus: nullius momenti esse (Adv. haer. iv. 6I. I). Symmachus: magni momenti esse (Ep. vii. I 8 ), tanti momenti esse (Ep.iv. 53). Augustine: alicuius ponderis aestimare (Contr. Faust.xi. 2).

Paulinus Nolanus: eiusdem pretii esse (Appendix. Ep. ad Celanc. 21), incomparabilis pretii ducere $(E p . x i$. I).

Orientius: pretii esse (Common. ii. I1 3 ).

Salvianus: parvi pretii esse (Ad. eccles. iii. I8. 84 ).

Claudian: nullius momenti esse (De stat. an. i. 25).

Digest: magni pretii esse (xlvii. 2. I4. 5), nullius pretii esse (xxi. I. 43.6), nullius momenti esse (passim), minimi aeris esse (xxxiv. I. 3), magni pretii facere (xiii. 7.25 ).

Codex: nullius momenti esse (i. $3 \cdot 36-37$ ).

We see from these examples not only that preti occurs as frequently in the later authors as in the earlier but also that side by side with preti there has been developed a series of substantives of similar significance: momenti, mominis, ponderis, aeris. Moreover, these substantive expressions of value show growth in the range of the verbs with which they are used; for, while in Plautus and Terence the only verb found with preti is esse, in Cicero putare (with momenti) occurs, in Columella ducere (cf. also Paulinus Nolanus), in Lucifer and in the Digest facere. In brief, so far as the phenomena presented by the language in the literary period may be regarded as an index of the trend of development in the pre-literary period, the probability of magni facere, etc., going back to an original magni preti facere is extremely remote.

Further, the proposed derivation from the genitive of quality leaves out of consideration two important groups that belong to the category of valuation. One of these consists of the combinations already referred to: boni consulere, aequi bonique facere, pensi ducere, in which we have examples of the neuter of the adjective without any indication of the omission of a substantive. Nor are these of late origin, formed on the analogy of the use of magni, parvi, etc. Boni consulere is an old phrase as we know from Quintilian, ${ }^{17}$ aequi facere occurs in Plautus, aequi bonique facere in Terence. The other group includes the expressions in

${ }^{17}$ Inst. Or. i. 6. 32 Sit enim 'consul' a consulendo vel a iudicando: nam et hoc 'consulere' veteres vocaverunt, unde adhuc remanet illud 'rogat boni consulas.' 
which nihili, flocci, nauci, etc., are used with verbs of rating. The fact that these genitives occur regularly without an adjective separates them from the class of the genitive of quality, in which the presence of the adjective is an element of the utmost constancy.

Apparently this theory established itself in the older handbooks before the publication of the works of Brugmann, Delbrück, Wackernagel, and Bennett, and has maintained itself in some more recent grammars in spite of the results of the investigations of these scholars. For acceptance of the theory involves assumptions that must now be regarded as extremely doubtful, if not wholly unsound. For instance, some of those who have adopted it seem to have been led to do so by the belief that the original use of the genitive case in the IndoEuropean mother-tongue was adnominal, and that where we find parallel adnominal and adverbial uses as in this construction, it is probable that the latter is derived from the former. But there is no proof that the adnominal use of the genitive is earlier than the adverbial, and some investigators take the opposite view. Delbrück, ${ }^{18}$ for example, says: "Abweichend von der gewöhnlichen Ansicht bin ich eher geneigt, den adverbialen Genetiv für den ursprünglichen zu halten," and with this view Brugmann ${ }^{19}$ agrees: "Ich stimme in der Hauptsache bei, nämlich darin, dass der Genetiv in Abhängigkeit von Substantiva das Sekundäre war." But unsatisfactory as this assumption is when applied to the genitive as a whole, it is especially unsatisfactory when applied to the particular construction which we are discussing. For the very foundation of the theory is shaken by the fact that it has never been demonstrated that there was a genitive of quality in the IndoEuropean language. Wackernagel's arguments in favor of it (op. cit., p. I35) are not convincing, and I am inclined to favor the view expressed by Delbrück, ${ }^{20}$ who says: "Ein solcher [i.e.,genetivus qualitatis] findet sich in den arischen Sprachen und im älteren Griechisch nicht oder nur selten vor. Dagegen ist er belegt im Lateinischen, Germanischen, Litu-Slavischen. Es ist nicht unwahrscheinlich, dass dieser Genetiv sich nach Auflösung der alten Komposita entwickelt hat." In Homer, for example, it is compound adjectives, not genitives of value or description, that we find. A complete examination ${ }^{21}$ of the Iliad and

${ }_{18}^{8}$ Vergleichende Syntax der indogermanischen Sprachen, p. 308.

${ }^{19}$ Gricchische Grammatik, p. 39r. Cf. also Wackernagel, Genetiv und Adjectiv, in Mélanges de Saussure (Paris, I908), p. I46; and Bennett, Syntax of Early Latin, II, 8, I0.

${ }^{20}$ Op. cit., p. 348 .

${ }^{21}$ The search was made by Dr. Alice Bräunlich, and I am indebted to her for the examples quoted. 
the Odyssey shows that no pure examples of the descriptive or qualitative genitive are forthcoming, although approaches to it do occur: e.g.,

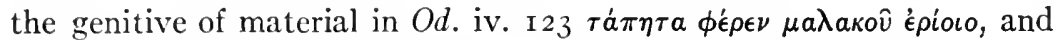

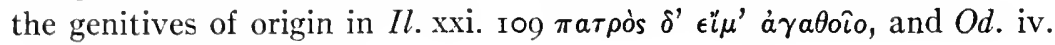

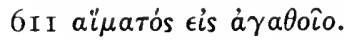

A further comparison with Greek usage increases the probability that the Latin genitive of value was not a development of the genitive of quality, for in Greek we find the genitive of value and price in regular use, although the genitive of quality was a late and unimportant development in that language. In Attic the genitive of value is found with verbs of rating ( $\dot{\alpha} \xi \iota \hat{\omega}, \tau \dot{\alpha} \sigma \sigma \omega, \tau \iota \mu \hat{\omega}, \pi \circ \iota \hat{v} \mu a \iota)$, with verbs of buying and

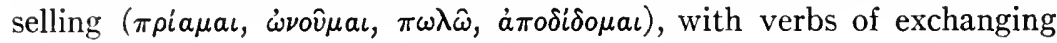

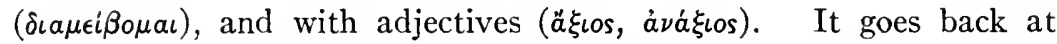
least as far as Homer, for it is this genitive that we find with a verb of

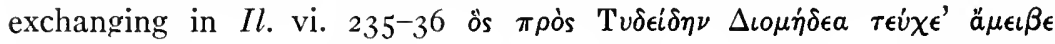

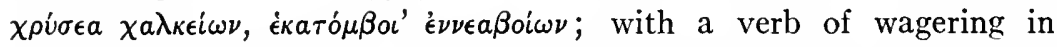

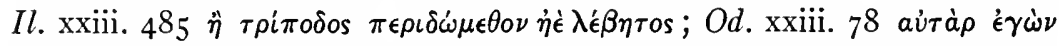

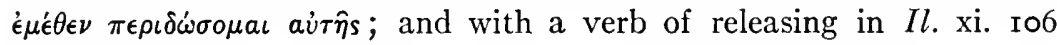

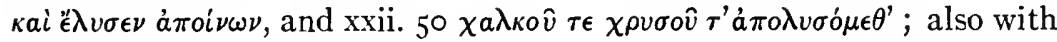

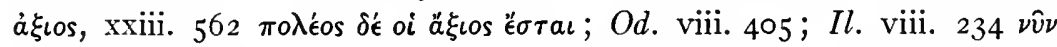

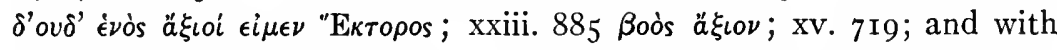

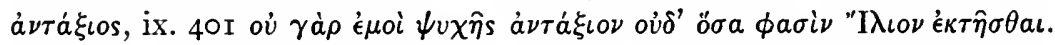
If then we find in Greek a genitive of value which was developed without any influence from a genitive of quality, it is clear that the genitive of value in Latin could have arisen independently of the genitive of quality, and it is probable that it did so. Nor need we look for substantives to supply with magni, parvi, etc., since we find $\pi \circ \lambda \lambda \circ \hat{v}, \pi \lambda \epsilon i o \nu o s$, and $\pi \lambda \epsilon i \sigma \tau o v$ without a substantive or suggestion of one used freely in the sisterlanguage.

\section{d) Wackernagel's Explanation}

An entirely different view is expressed by Wackernagel in his article Genetiv und Adjektiv. ${ }^{22}$ He draws attention to the usage in Sanskrit in which the suffix $(\bar{a})$ of stems in $a, \tilde{a}, i, r$, an, and a few in $a s$ may be changed to $\bar{i}$, and this form be combined in the manner of a verbal prefix with $k r-$, "make" and bhu-, "become."23 The combination shows different shades of meaning. Sometimes its significance is merely "to make or become something," while in other contexts it means "to make or

${ }^{22}$ Op. cit., pp. I $29-37$.

${ }^{23}$ Cf. also Whitney, Sanskrit Grammar, rog4. 
become a participant of something" or "to bring or come within the field of something." To this Sanskrit combination Wackernagel sees a parallel in the use of the Latin genitive in $-\bar{\imath}$ with facere and esse to express value and other concepts. ${ }^{24}$ He cites such examples as multi facere, maximi facere, tanti facere, nihili facere, flocci facere, nihili esse, tanti esse, etc. He is of the opinion that these $-\bar{\imath}$ forms were the first in the field in this construction, but that later they were followed by such genitive forms as minoris, pluris, etc. In the same process of development the original verbs of valuation facere and esse were frequently replaced by others (pendere, aestimare, etc.).

This is an ingenious theory and has been adopted by Bennett as the basis of his latest treatment of the construction.25 That it is correct in regarding the genitive of value as originally adverbial, there is, I believe, no doubt. This point I have already discussed (see p. 5). It is correct also in its implicit recognition of certain points of contact between the genitive of value and the partitive genitive. But it is open to criticism on the ground that it limits to forms in $-\bar{\imath}$ a function which seems to have belonged to the genitive case as a whole. It is hardly likely that such simple concepts as "to be of more value" (pluris esse), "to be of less value" (minoris esse), only found expression after the development of analogical influence. And the fact is that, in addition to their very frequent use with $-i$ forms and with pluris and minoris, the Latin verbs of rating were freely combined with other genitive formations: e.g., cauniarum, sescunciae. The group of Sanskrit combinations cited by Wackernagel furnishes an interesting parallel to the Latin genitive of value but is inadequate as an explanation of its origin. Moreover, it should be pointed out that the expression of valuation in Sanskrit itself followed wholly different lines.

e) Conclusion: The Genitive of Value an Original Adverbial Construction: One of Several Instances of the Free Use of the Genitive with Verbs Expressing Various Phases of Connection or Relation. Influence of the Genitive of Quality.

For my own part, in determining the origin, I would go farther than Wackernagel, and would explain the most representative types, pluris and minoris, as well as magni, parvi, etc., as examples of an original free use of the genitive with verbs. Nor is the nature of this original adverbial genitive difficult to determine. Much of the uncertainty that has

${ }^{24}$ He quotes Ludwig, Sitzungsberichte der böhmischen Akademie, VII (I897), I I.

${ }^{25}$ Op. cil., II, 93 ff. 
existed in regard to this problem has been due to the rigidity with which the older grammarians have treated the genitive as a whole, insisting that all the constructions of the case must be traced back to one or at most two original forces. Many (Reisig among them) have emphasized the partitive idea; some have even claimed that this was the original force of the case. Others have recognized two original forces, the partitive and the possessive, without expressing their opinion as to which was the earlier. But the attempt to classify the mass of genitive constructions found both in Greek and Latin under one or other of these heads has never led to satisfactory results. The conclusion to which one is inevitably driven is that in setting up "original forces" grammarians have fallen into the error of making their compartments too narrow. The earliest data available seem to indicate that the original function of the genitive was of wide range. Brugmann's statement is quite as true of the Latin genitive as of the Greek: "Ziehe ich es vor zu sagen der Genetiv lässt den Nominalbegriff als eine Sphäre, als einen Bereich erscheinen, zu welchem die durch das Verbum ausgedrückte Thätigkeit in irgend einer Weise in Beziehung steht oder tritt." ${ }^{26}$ Of this wide function the possessive genitive is one phase, the partitive another, the genitive of valuation another, and still others are forthcoming. There is no ground for regarding these categories as derived one from another. They are to be thought of as different types of a general idea of connection; they are a series of conterminous groups, for the most part distinct but at some points merging into one another by subtle indistinguishable stages, as the genitive of valuation into the partitive (e.g., pensi, aequi, boni), and the partitive into the possessive.

But while in magni, boni, nihili, etc., combined with facere, pendere, etc., we have the most characteristic type of the genitive of value, this did not remain the only occupant of the field. The partitive origin of aequi, boni, and pensi has already been commented on. Other constructions were also employed. One of these was the genitive of quality. As I have said, this is probably not of Indo-European origin, but once established in Latin it was readily adaptable for the purpose of expressing valuation. Indeed any genitive of quality in which the noun was a word meaning or connoting value (e.g., res magni preti) was substantially a genitive of value.

The following list contains all the examples of the attributive genitive of valuation which I have found. Two types are represented: (I) that in which the valuation is expressed by a noun and an adjective;

(2) that which consists of a noun alone.

${ }^{26}$ Op. cit., p. 385 . Cf. Bennett, op. cit., II, ro. 


\section{(I) Noun with Adjective}

Magni preti in Plaut. Cas. 98 vilice haud magni preti; Curc. 167 homo haud magni preti; Mil. I45; Stich. 235; Cic. Tull. 9. 2 I magni preti servus; Liv. xxxv. 40. 8 cum magni pretii mercibus.

Maioris preti in Ter. Heaut. 64 meliorem agrum preti maioris; Cic. Invent. i. 3 I. 5 r ornatum muliebrem preti maioris; Liv. v. 21. 14 praeda ... . maior maiorisque pretii rerum; Gell. xi. I. 2 boves ovesque alias pretii parvi, alias maioris; Dig. xii. 6. 26. 4 maioris pretii res.

Maxumi preti in Ter. $A d .89 \mathrm{r}$ hominem maxumi preti.

Multi pretii in Apul. Met. ix. 4r multi pretii vasculum.

Pretii pluris in Varr. $R . R$. i. 7. 4 ut plus reddant musti et olei, et pretii pluris; Dig. xii. 6. 26. 5 oleum . . . pluris pretii.

Parvi preti in Plaut. $A u l .790$ nullus tam parvi preti; Liv. xxi. 60. 8 praeda oppidi parvi pretii rerum; xxv. 3. II.

Minumi preti in Plaut. Cas. 573 vir minumi preti; Bacch. 444 senex minumi preti; Men. 489 ; $A \sin .85^{8}$; Epid. 494; Liv. xli. 23. 8 servulorum minimi pretii. Quantivis preti in Plaut. Epid. 4 ro servom graphicum et quantivis preti.

Abiecti pretii in Apul. A pol. 93 neque pauca neque abiecti pretii.

Nullius pretii in Auson. Cent. Nupt. I (Sch. p. 140) frivolum et nullius pretii opusculum.

Trium cauniarum in Petron. Cen. 44 sed quare nos habemus aedilem trium cauniarum?

Maximi momenti in Liv. xliii. 23. 8 in rem maximi ad omnia momenti.

Maioris ponderis in Eugipp. Exc. cclxxix. 304 et fortasse maioris ponderis bona.

\section{(2) Noun without Adjective}

Nihili in Plaut. Cas. 559 illum nihili, decrepitum; Truc. 599 novi hominem nihili; 695 heu edepol hominem nihili; Mil. r80; 285 edepol, Sceledre, homo sectatu's nihili nequam bestiam; Pers. I 20 ; Merc. I25 nimi' nihili tibicen siem; Asin. 859 ; Stich. r89 nihili quidem hercle verbum id ac vilissimum. It is used in address in Truc. 333 inprobe nihilique homo; Bacch. 904 ne supplicare censeas, nihili homo; Trin. ror 7 quid, homo nihili, non pudet te? Asin. 472; Cas. 239 tu nihili; 245 unde is, nihili? Ennius Sat. 494 B writes illic nugator nihili; Front. $225 \mathrm{~N}$ herbas et holuscula nihili; Gellius ii. I4. 2, speaking of the change from "stitisses" of Cato to "stetisses," says tamquam "stitisses" vanum et nihili verbum esset; iv. 20. I I Statius nihili servus; xvii. 6. 3 servus nihili; vi (vii). II. 2 ; xv. 2. 2; in address x. 19. 2: homo, inquit, stulte et nihili; Lactantius, De orig. error. ii. 1. 2, in a climax: infirmos et supervacuos et nihili et frustra omnino natos; Auson. Technopaeg. 3. r6 iocus ac nihili res; Symm. Ep. i. 75 (69) nihili negotium.

Nauci in Plaut. Truc. 6I I hominem non nauci; Bacch. I IO2 servom meum non nauci.

Sescunciae in Pompon. Bon. I I I (R) pappus hic mendicus habitat, senica non sescunciae. 
Sextantis in Laber. ap. Gell. xvi. 9. 4. servus sextantis.

Semissis in Cic. Fam. v. ro a. x (a letter of Vatinius) non semissis homo. Tressis in Pers. v. 76 non tressis agaso.

Trioboli in Plaut. Poen. $38_{1}$ non homo trioboli; $46_{3}$. The expression is

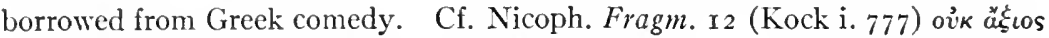

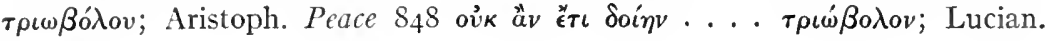
Tim. 24 .

In type (I) we have nothing more or less than examples of the genitive of quality in which the noun happens to express the idea of valuation. In type (2) we see a modification of the genitive of quality under the immediate influence of the genitive of value. The absence of the epithet removes this group from the category of the normal genitive of quality. Another illustration of the influence of the genitive of value working back into the genitive of quality is seen in the list of adjectives used with preti in the examples of type (I). These were doubtless largely determined by the genitives in common use with the verbs of rating. Still another instance of the contributions made to the genitive of quality by the genitive of value is furnished by the combination pretii pluris. For, as plus is a substantive, such an expression could have arisen only under the influence of the extremely common use of pluris with facere, esse, etc. On the other hand we must attribute to the influence of the genitive of quality the adverbial use of maioris, which seems to occur first in Phaedrus (with a verb of selling) and later in Seneca and Tertullian. For in genitives of quality it occurs as early as Terence, and then in Cicero, Livy, and other authors.

\section{THE GENITIVE IN INDEFINITE VALUATION}

a) magni, pluris, maximi, etc.

(I) Magni

With facere:

Plaut. Pseud. 577 ut eas magni facias; 944; Asin. II 4 ; 214; 407; Cist. 2x; Ter. Ad. 879 me amari et magni fieri postulo; Lucil. 1336 (Marx); Turpil. in Non. I. 203 (L) meritissimo te magni facio; Cic. Fam. xiii. I6. I; Quint.fr.i. 2. 7; Liv. ii. I3. 8 alias haud magni facere; Apul. Dogm. Plat. ii. I6; Gell. vi (vii). 3. 47 ; xi. 7. 3; Latin version of Irenaeus Contr. haer. i. 28. 7 ; Dig. i. 16. 4. 5 (Ulpian); xliii. 24. I. Iо.

With pendere:

Plaut. Stich. 135 mendicos homines magni penditis; Curc. 262; Pseud. 22r; Asin. 460; Lucret. vi. r276; Hor. Sat. ii. 4. 93; Sen. Vit. Beat. 10. 3; Tac. 
Ann. xii. 18. 4 ; Gell. xvi. 9. 3; Aug. Contr. Faust.xvi. 20; Quaest. i. I6r; iv. 25; De pat. I I. 9; Eugipp. Exc. Ixxxviiii. 104; cxxii. I38; cccxxxviiii. 375 .

With pensitore:

Apoll. Sidon. Epist. iv. I4. 4 si futura magni pensitas.

With esse:

Cic. Fam. xiii. 72. 2 scio enim eius ordinis auctoritatem semper apud te magni fuisse; xv. I5. 4; Att. x. 8A. I; Nep. Dat. I. 2 ; Con. I. I; Sen. Q.N. vi. 32 . I0.

\section{With aestimare:}

Cic. Att. ii. 4.7 magni aestimo unius aestatis fructum; vii. I 5. 2; x. I. I ; xii. 28. г; xiii. 19. 3; Fam. xiii. 16. 3; Quint.fr. ii. I4 (15b). 3; Ad Brut. i. 9. 2; Pet.cons. (Q. Cic.) 7. 26; Mur. 4. Io; Fin. ii. 17. 55; iii. 13.43; Tusc. iv. 37.79; v. 7. 20 ; Sen. Ep. 95. 55 ut prudentiam magni aestimemus; Ben. i. I. 7 ; Q.N. vi. 3. 3; Fragm.xv. 99 (Haase); Col. viii. 16. 2; Plin. Ep. iii. 2.5 ; iii. 4. I; iv. 28. I; vi. 23.3; Suet. Ner. 2 I; Vesp. 15; Lact. Divin. inst. ii. I. 4; v. 9. I 2; Lucifer Moriend. 3; Aug. De div. daem. 2. 5; Dig. ix. 2. 26; ix. 38. 2. 36.

With existimare:

Nep. Cat. I. 2 magnique opera eius existimata est in proelio apud Senam; Suet. Aug. 40 magnique praeterea existimans ..... incorruptum servare populum; Aug. Quaest. v. 3 I magni extimantur (sic) haec ab hominibus.

\section{With habere:}

Caes. B.G. iv. 2 I. 7 cuius auctoritas in is regionibus magni habebatur; Aug. Quaest. i. I6r.

With putare:

Cic. Flacc. 4I. 104; Planc. 4. II.

With ducere:

Aug. De div. daem. Io. I4, quoting Es. li. 7. 8: nec quod vos spernant magni duxeritis.

For magno see p. 34 ; pro magno, p. 39.

\section{(2) Maioris}

With esse:

Tertull. De ieiun. I7 sed maioris est agape; cf. the use of maioris with a verb of selling: Phaedr. ii. 5. 25 multo maioris alapae mecum veneunt; Wölfflin (op. cit., p. I05) refers to an example in Seneca, but does not cite the passage.

For maiore see p. 34 . 


\section{(3) Maximi}

With faccre:

Plaut. Cas. prol. 2 fidem qui facitis maxumi; Ter. Andr. 293; 574; Cic. Fam. xvi. I5. I.

With aestimare:

Cic. Fam. xi. 28. I (a letter of Matius) quia maximi aestimabam; Cluent. 58. 159.

\section{(4) Multi}

With facere:

Plaut. Rud. 38 I verum ecastor ut multi fecit; Cato in Festus (Th. de P. 143): multifacere dicitur sicut magnifacere et parvifacere. Cato: "neque fidem, neque insiurandum, neque pudicitiam multifacit"; quod merito ab usu recessit, quia quantitas numero non aestimatur, nec desiderat multitudinem.

For multum see p. $4 \mathrm{I}$.

\section{(5) Pluris}

With facere:

Naevius (Ribb. frag. 3) ego semper pluris feci . . . . libertatem; Plaut. Trin. 34; Curc. 580; Cic. Fam. i. 9. I5; ii. 13. 2 ; iii. 4. 2; xiii. 55. I; xiii. 64. I; xiii. 67. I; Att. iii. 10. 2 ; v. 9. 3; vii. I. 3; viii. 2. 4 ; Ad Brut. ii. 3.6; Tusc. i. 37. 9o; Nep. Dat. 5. 2; Iphicrat. 3. 4; Sall. Cat. 52. 5 ; Liv.xxviii. 4 I. I; Auson. Eclog. lib., Ausonius Drepanio filio I I; Lact. Div. inst. iii. 9. I 2.

With pendere:

Aug. De mag. ix. 25 (twice); ix. 26; De mend. 20. 41 .

With esse:

Plaut. Mcrc. 5 I4 oratio edepol pluris est huius quam .... ; Asin. 435; Cic. Att.v. 20.6 ; ix. 13.6; xii. 28.2 ; xii. 47.3 ; xvi. 5.2 ; Fam.vii. 10. 4 ; vii. I1. 2 ; ix. 19. 2 ; xvi. I1. 3; Pet. Cons. (Q. Cic.) 3. I1; Flacc. 37.19; Rosc. C. 12.33; Prov.Con. 5. 12; Sest.68. 142; Planc. 20.50; Rep. iii. 9. 16; N.D.ii. 12.32; Fin. iii. I. I; iii. I3. 44 ; v. 21. 60; Tim. 4. I 2; Cat.M. 17.61; Off. i. 45. I60; Nep. Epam. 10. 4; Liv. 39. 44. 2; Hor. Sat. i. 9. 7; Ov. Fast. i. 197; Phaedr. iv. 25. 2; Sen. Ep. 29. 7; Bcn. vi. I5. 2; vi. I5. 3 ; vi. I 5. 4 ; vi. I6. 3 ; Mart. iii. 62.6; iv. 29. 10; Juv. viii. $25^{8}$; Fest. I64 (Th. De P.); Latin version of Irenaeus $A d v$. haer. ii. 46. 4; Lact. Divin. inst. iii. 9. I6; Vulg. Matth. 6. 26; Symm. i. 2 I (16); Aug. Contr. Faust. xxxii. 6; De op.mon. 27.35; Dig. viii. 2.55; x.3.6.9; xii.3. I; xix. 1.3.3; xix.2.22.3. 
With aestimare:

Cic. Fam. x. 5. I; xi. 3. 4; Verr. iii. 84. 195; Scaur. 22.45; Fin. iii. 6. 21; iii. II. 39 ; iii. I3. 43 ; iii. I 4.47 ; v. 30.90 ; v. 32.96 ; Paradox vi. 2.48 (three times); Acad. i. Iо. 37 ; Off. iii. I 5. 62; Liv. vii. 4 1. 7 ; xxxix. 44.3 ; Sen. Ep. 81. 6; 81. 19; Ben. ii. 3. 2; Plin. H.N.ix. I8.31; Aug. De bon.con. 29; Eugipp. Exc. ix. 23.

With existimare:

Plaut. Pers. 353 non ego inimicitias omnis pluris ${ }^{27}$ existumo quam; Plin. H.N. xxxv. Io. 94 divus Claudius pluris existumavit.

\section{With habere:}

Cic. Phil. vi. 4. Io pluris habetur quam L. Trebellius, pluris quam T. Plancus; Ovid. A.A. ii. I44 aliquid corpore pluris habe.

\section{With putare:}

Cic. Att. xii. 2 I. 5 ; Off. iii. 4. I8; N.D. iii. I0. 26; Fam. x. I 5. I (a letter of Plancus) ut se liberos urbemque pluris ... . putaret; Sen. Ep. 95. 59 pluris quaedam quam sunt putas.

With ducere:

Cic. Att. vii. 3.8 pluris ea duxit quam omnem pecuniam.

\section{With licere:}

Hor. Sat. i. 6. I3 non umquam . . . p pluris licuisse.

With valere:

Symm. Ep. ii. 30. 4 non pluris apud me divitias valere quam famam.

For plure see p. 34; plus, p. 4I.

\section{(6) Plurimi}

With facere:

Cic. Fam. iii. 4. I me a te plurimi fieri; iii. 4 . 2 ; iii. Io. 2 ; vi. 6.4 ; vii. 3 I. I; xiii. 4. I; xv. I4. 2; xvi. 9. 2; Quint.fr. ii. 4. 7; Sex. Rosc. I6. 47.

\section{With pendere:}

Plaut. Bacch. 207.

With esse:

Cic. Ad Brut. i. I2. I quod mihi plurimi est; Fin. iii. I4. 47; Paradox. vi. 2. 48 ; Dig. xiii. I. 8. See also quanti, p. 20.

${ }^{27}$ This is the reading of $\mathrm{A}$ and is adopted by Götz and Schöll (Leipzig, I895) and by Leo. But Schöll ( $2 \mathrm{~d}$ ed.) reads flocci existumo. Lindsay has plure existumo. 


\section{With aestimare:}

Cic. Att. v. 12. 3 quam cgo .... acstimo plurimi; Quint. fr. ii. I3. I; Fin. iii. 10. 34 .

\section{(7) Parvi}

With facere:

Plaut. A $u l$. I1 2 pauxillum parvi facere quin nummum petat; Mil. 135r; Pompon. in Non. (L. p. 26) ego rumorem parvi facio; Titin. in Non. (L. p. 8I6); Sall. $J_{\text {ug. }}$ 85. 3 I ; Liv. viii. 36.2 ; xxxv. 49. 3; Apul. Met. ix. I3; Gell. ii. 28. 7 ; Symm. ii. 36.4 ; ii. 45 ; Cod. Iust. x. 32 (31). I6.

With pendere:

Plaut. Rud. 650 qui deos tam parvi pendit; Trin. 102; Bacch. 558; Ter. Hec. 513; Heauton. 715; Andr. 526; Sall. C. I 2. 2 sua parvi pendere; 52. 9; Sen. Ben. i. 5. 2 illud quod in re carum atque pretiosum est parvi pendunt; Apul. Met. iv. 25; ix. 36; Cyprian. Append. De duod. abus. saec. I; Macrob. Somn. Sc. ii. 9. Io; Aug. De Gen. ad litt. imperfect. lib. 16; Oros. Adv. pagan. i. 2 I. I7; iii. I4. 6; v. I. I; vi. I 5. I4; vii. 38 . I; Salv. Ad eccles. iv. 5.27 (perparvi); Eugipp. Exc. 23 ; Gregor. Hist. Franc. iii. 18; iv. 36; ix. 6; ix. 35; x. I $5 ;$ In glor.mart. $22 ; 47 ; 78 ;$ Vit. patr. viii. $5 ;$ In glor. confess. $78 ; 79$.

With esse:

Plaut. Pers. 690 nil mihi tam parvist, quin .... ; Cic. Att. xv. 3. I sed sunt ista parvi; Nep. Eum. 10. 4; Ov. Met. iv. 654 .

With aestimare:

Cic. Invent. i. 45.83 qui id parvi . . . . aestimet; Liv. xxi. 43. I7; Sulp. Sev. Chron. i. 39. 2; Salv. Adv. eccles. iv. 1. 2; Eugipp. Exc. cccxxxvi.

With existimare:

Plaut. Capt. 682 dum ne ob malefacta peream, parvi existumo; Sulp. Sev. Appendix. Epist. ii. 3 pudicitiam aut nullius praemii aut parvi existimat.

With habere:

Symm. Epist. v. I4 quam quia religio parvi habuit; vii. 66; Laud. in Valent. i. I9 praeceptum parvi habitum.

With putare:

Catull. 23. 25 haec .... commoda . . . noli spernere nec putare parvi. With ducere:

Cic. Arch. 6. I 4 omnia pericula mortis atque exilii parvi esse ducenda; Fin. ii. 8. 24 quia parvi id duceret; Val. Max. ii. 7. I5; Arnob. Adv. nat. ii. 76 minas omnes .... parvi ducere atque aestimare.

For parvo see p. 34 . 


\section{(8) Minoris}

With facere:

Plaut. Epid. 522 ac me minoris facio; 66r; Cic. Sex. Rosc. I6. 46; Liv. xxiv. 9. I I.

With pendere:

Plaut. Most. 883 minoris pendo tergum illorum quam meum; 21 5; Aug. De lib. arbitr. i. 6. I4.

With esse:

Cic. Att. xiii. 29. 3; N.D. ii. 1 2. 32; Sen. Clem. i. 21. 4; Mart. xii. 66. 9; Gell. iv. 2. 5 ; Dig. xviii. 2. I5; xix. 1. 3. 4 .

With aestimare:

Cic. Fin. iv. 20. 57 paulo minoris aestimavisset ea quae; another example in the same section; Acad. i. 10. 37 ; Att. ix. 9. 4 ; Nep. Cat. i. 4 ; Sen. Ep. 73. I2; Dig. xxiii. 3. I2. I.

With existimare:

Sulp. ap. Cic. Fam. iv. 5.2 omnia minoris existimare.

With putare:

Cic. Planc. 20. 50 quod minoris putaris.

With valere:

Dig. v. 3. 25. I si res minoris valet quam comparata est; xlvii. 2. I4. 5.

\section{(9) Minimi}

With facere:

Plaut. Pseud. 269 eos minimi facit; Cic. Fin. ii. I3. 42.

With habere:

Fest. I 46. 29 (Th. de P.) minimi habeatur Pomonalis.

With putare:

Cic. Fam. i. 9. 5 quae a me minimi putabantur.

For minimo see p. 35 .

\section{(1o) Tanti-Quanti}

With facere:

Cic. Fam. iii. IO. I quod tu si tanti facies quanti ego semper iudicavi faciendum esse; iii. 10. 10; iii. 13.2; vi. 9. 2 (tantus-quanti), x. 1. 4 (tantiquantum); xi. 16.3; xvi. 4 . 4 (quantam-tanti); Att. xii. 37. 2; Sex. Rosc. 39. II 5 (tantidem-quanti); Lacl. I6. 56; I6. 59. 
With facere-existimare: sentio.

Cic. Fam. xiii. Io. 4 si me tanti facis quanti et Varro existimat et ipse With esse:

Plaut. Bacch. 82I tantist quantist fungus putidus; Cic. Rep. iii. 35. 48; Caecil. Balb. I55 (Friedrich's edition of the Sententiae of Syrus); Dig. xvii. 2. 29. I. Cf. also Sen. Ep. 85 . I 2 tanti erunt quanto fient; Cic. De or. ii. 52. 209 (tanti-quanta-quantum); Hor. Sat. i. I. 62 (tanti-quantum); Sen. Ep. 87. I5 (tanti-quantum); I15. I4 (tanti-quantum); Apul. Apol. 23 (tanti-quantum).

With esse-aestimare:

Cic. Verr. iii. 84. I94 si . . . frumentum tanti fuit quanti iste aestimavit.

With esse-taxare:

Sen. Cons. Marc. 19. I tanti quodque malum est quanti taxavimus.

With aestimare:

Cic. Fam. vii. 23. 2; xv. 21. 2; Verr. iii. 92. 21 5; iii. 95. 22I; Paul. ex Fest. 4I. 3 (Th. de P.) tanti-quantum); Dig. vi. I. 46 (Paulus); xiii. 4.8 (Africanus); Just. Inst. ii. 4. 2 (tanta-quanti).

With existimare:

Aug. Contr. Faust. xiv. i.

\section{(II) Tanti}

With facere:

Plaut. Merc. 6 quos pol ego credo humanas querimonias non tanti ${ }^{8}$ facere, quid velint, quid non velint; Cic. Att. iv. I2. I; viii. г5A. 2; ix. 7B. 3 ; x. 8A. I; Fam.xiii. 55. I; Planc. I1. 28; Phil. xi. 13.35; Lael. Ir.37; Nep. Timoth. 4. 3; Petron. Cen. 62; Tertull. Ad. nat. i. 7; Nolan. Epist. xxiii. 39.

With pendere:

Oros. Hist. adv. pagan. iii. 23. 65 tanti apud illos divina atque humana religio pendebatur.

With esse:

From the time of Cicero on tanti esse, non esse is used idiomatically with varying force. It has considerable range, occurring here and there

${ }^{28} \mathrm{In}$ this passage tanti is doubtless accompanied by some gesture (see p. 30), though one can hardly accept the suggestion made by Wyss (Sprickworter, III) that the speaker points to dirt under his finger nail. 
in all the works of Cicero, in Livy, Ovid, Phaedrus, Columella, Seneca, Lucan, Silius Italicus, Martial, Juvenal, Pliny, and the Church Fathers, but turning up most frequently in writings that are more or less colloquial, e.g., in the letters of Cicero, Seneca, and Pliny, in the lighter works of Ovid, and in the Epigrams of Martial. The shifting significance of the expression has been acutely analyzed by Madvig, ${ }^{29}$ and the categories given below are his. To his interpretation I have nothing to add, and I set down the examples I have found merely for the purpose of indicating with greater fulness the range and frequency of the different uses:

I. Where something, desirable in itself, is or is not sufficient consideration for the performance of some act or the endurance of some hardship. Sometimes a person is the subject. It is generally negative or virtually negative.

Cic. Caccin. 7. I8 non putavit esse tanti hereditatem, ut de civitate in dubium veniret; Cael. 15. 36; Sull. I6. 45 mihi cuiusquam salus tanti fuisset, ut meam neglegerem? Rosc. Com. 8. 22 HS. I000 tibi ... certe tanti non fuissent ut socium fraudaretis; Fam. viii. I4. I (Caelius) tanti non fuit Arsacen capere et Seleuceam expugnare, ut earum rerum, quae hic gestae sunt, spectaculo careres; Att. xi. r6. 2 sed ego non adducor quemquam bonum ullam salutem putare mihi tanti fuisse, ut eam peterem ab illo; xii. 3. I ne vivam, mi Attice, si mihi non modo Tuscu-

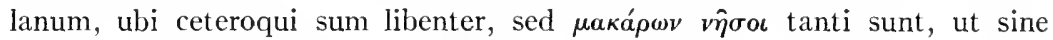
te sim tot dies; xiii. I4. I; Tusc. ii. 6. I6 quod decus erit tanti, quod adipisci cum dolore corporis velit.... ? Liv. xxv. I 5. 2; Ov. $A m$. i. Iо. 49; ii. 5. I nullus amor tantist . . . u ut mihi sint totiens maxima vota mori; iii. 6. 37 ; Rem. Am. 750 ; Heroid. I. 4 vix Priamus tanti totaque Troia fuit; 7.45 non ego sum tanti . . . ut pereas; 9. 10; 17. 225; 18. 97; Met. ii. 659 non fuerant artes tanti, quae numinis iram contraxere mihi; vi. 386 ; xi. 779; Fast. vi. 7or; Ex Pont. iii. 9. 45; iv. 6. I 2 nec fuero tanti; Trist. ii. 209 nam non sum tanti, renovem ut tua vulnera, Caesar; Phaedr. iii. I. 4 tanti non est ingenium tuum, momentum ut horae pereat officiis meis; Sen. Clem. i. 9. 4 non est tanti vita, si, ut ego non peream, tam multa perdenda sunt; Q.N. i.

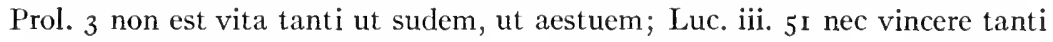
ut bellum differret erat; Sil. Ital. xvii. ı86; Plin. H.N. xxi. 3І. г8г; xliv. 45. I45; Mart. i. Io8. 6 est tanti, vel si longius illa foret; i. II7. I8 tanti non es; v. 22. I2; xi. 7I. 3 ; xii. 43 . I I xii. 48 . I I Iuv. iii. 54 tanti tibi non sit opaci omnis arena Tagi quodque in mare volvitur aurum, ut somno careas; vi. I78; x. 97; Tac. Dial. 40 ; Ann. vi. 2. 17 ; Plin. Ep. viii. 9. 2 nulla enim studia tanti ut amicitiae officium deseratur; Pan. 37 fin.; Tertull. Ad nat. ii. 9

${ }^{29}$ Opuscula Academica (2d ed.), pp. $549^{-56}$. See also American edition of his Latin Grammar, p. 257, Obs. 3 . 
nos responsionem opponamus necesse est, neminem ex his quoque tanti fuisse; Lact. Divin. inst. i. 9. 7; iii. 8. 7; iii. I2. 20 tanti est . . . contemplatio caeli ac lucis ipsius, ut quascumque miserias libeat sustinere; Auson. Caes. Domit. 3 vix tanti est habuisse illos, quia dona bonorum sunt brevia; Ep. 5. 15; Claudian. Bell. Goth, 99; Rufin. ii. 249.

2. Where there is no definite subject: est tanti, "it is worth while," nihil est tanti, "it is not worth while."

Cf. Cic. Terr. fuit tanti, mihi crede; iv. 20. 43; Cat. i. 22; Fam. viii. 3. I (Caelius) est tanti? est mehercules; Att. ii. I3. 2 iuratus tibi possum dicere nihil esse tanti; v. 8. 3 nihil nobis fuerat tanti; v. 20. 6 ; xii. 5 . 4 ; xiii. 42 . I; Brut. i. 16. 4; Hor. A.P. 304 verum nil tantist; Sen. Ben. ii. 5.2 inde illae voces quas ingenuus dolor exprimit: "fac, si quid facis" et "nihil est tanti"; Q.N. v. I8. 5 non erat tanti, si ad pacem per ista veheremur; Plin. Ep. iii. 9. 27 dices "non fuit tanti"; viii. I. 8 magno mihi seu ratio haec seu facilitas stetit, sed fuit tanti; Pan. 6 .

3. Where something, undesirable in itself, is or is not worth while bearing, in view of the consideration. This use emerges later than the other two.

Cf. Verg. Aen. iii. 453 tibi nequa morae fuerint dispendia tanti; Ov. Rem. Am. 75 I at tanti tibi sit non indulgere theatris; Met. ii. 424 sunt $O$ sunt iurgia tanti; Col. ix. 8. I4 neque est tanti vacua perdere complura; Sen. Cons. Helv. I2. 5 fuitne tanti servum non habere, ut colonus eius populus Romanus esset? Ben. iv. 39. 2 fuit tanti non revocare promissum suum; vi. 22 est tanti, ut tu coarguaris, ista concidere? Prov. 5. II est tanti per ista ire casuro; Q.N. ii. 59. Io at tu solatii loco numera tanti esse mortem tuam; Ep. 68. Io est tanti ab hominibus vinci dum a me fortuna vincatur! 76.4 sed est tanti, laborare omnia bona semel occupaturo; 82 . I 8 bonorum, ad quae pervenire tanti sit devorata unius mali patientia; Luc. ii. 62 vix tanti fuerat civilia bella movere; viii. 390 temptare pudendum auxilium tanti est, toto divisus ut orbe a terra moriare tua? Stat. Silv. iv. 3. 8r servitus . . . . tanti est, quod sub te duce ..... cessi; Sil. Ital. xii. 516 quam tanti fuerit cadere, ut Palatia cernas . . . . ; Mart. i. I2. I s sunt ipsa pericula tanti; viii. 69. 3 tanti non est, ut placeam tibi, perire; Iuv. xiii. 95 phthisis et vomicae putres et dimidium crus sunt tanti; Tac. Dial. 37 non quia tanti fuerit rei publicae malos ferre cives, ut ....; Front. Ep. ii. I4 tanti est minus lucubrare, ut te maturius videam; iii. i 7 sed tanti est me non recte scribere; Lact. Divin. inst. v. I3. I 5 sed tanti esse cruciari et emori, ne fidem prodat; vi. 9. 23 propter quae tanti sit et voluptates omittere et mala omnia sustinere. With aestimare:

Cic. Att. i. I8. 8 fac ut amorem nostrum tanti aestimes, ut . . ; Fam. vii. 23. 4; xv. 4. 13; Verr.iii. 75. 174; iii. 97.225; Acad.ii. 8. 23; Fin. ii. 28, 91; Suet. Tib. 48 . 
With existimare:

Cic. Mur. 16. $34 ; 3^{30}$ Att. i. 20. $2 ;^{30}$ Sen. Ben. vi. 35. 2.

With habere:

Lucil. (I 20 Marx) tantum habeas, tantum ipse sies tantique habearis; Dig. iv. 7. 4. I (Ulp.); Sulp. Sev. Vit. S. Mart. 25. 2; Ruric. Ep. i. I 5 (twice); ii. 8 ; ii. 16 ; ii. 22 ; ii. 28 ; ii. 29 ; ii. 32 ; ii. 42 ; ii. 48 . Ruricius' frequent use of tanti habere, with the force of "deign to," tends to confirm the reading suggested by Klein (Bonn. Jahrbuch, XCIII [I892], 203) and adopted by Bücheler in Carm. Epig. i. 794 qui mihi tanti (h)abeat ostendere vias suas qas ego sequere possem, an inscription which seems to belong to the second half of the fifth century after Christ.

With putare:

Cic. Mil. 23. 63 arbitrabantur eum tanti mortem P. Clodii putasse ut .... ; Ov. Met. x. 618; Sen. Ep. 53. 9; 77. г7; го4. 3; 11о. 6; Tranq. 8. 5; Plin. H.N. viii. 3. 4. 8; Plin. Ep. ii. 9. 6; iv. 26. 2; vi. 11. 4; Apul. A polog. 97 ; Lact. Divin. inst. vi. 12. 36 .

With ducere:

Cic. Rab. Post. 15. 41; Tert. De pudicit. 2.

With indicare:

Plaut. Pers. 66r qui datur, tanti indica.

With finire:

Val. Max. v. 3. 2a tanti poena finita est.

With taxare:

Plin. H.N. xvii. I. 7 qui vel frugiferas tanti taxaverant.

\section{(I2) Quanti}

With facere:

Cic. Fam. ii. I6. 5 qui scias quanti cum illum tum vero Tulliam meam

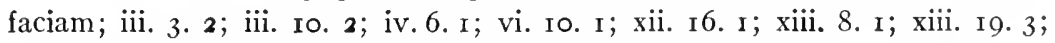
xiii. $29 . \mathrm{I}$; xiii. 29.3 ; xiii. 6 I ; xiii. $63 . \mathrm{I}$; xiii. 67.2 ; xiii. 79 ; xv. 10. 2 ; Att.i. 20.3 a senatu quanti fiam minime me poenitet; vi. I. Iо; xiii. I. 3 ; xvi. I6C. I0; Verr. iv. 9. I9 quanti is a civibus fieret .... ignorabas? iv. 24. 54; Mil. 36. 99; Frag. A. ix. 9 (Müller) populum . . . quanti faceret, ostendit; Tusc. i. 17. 39; Fin. iii. 2. 8; Sall. Jug. 24. 7; Hor. Ep. i. 9. 2; Plin. Ep. iv. I4. 6 ; Front. Ep. ad M. Caes. iv. 2.

${ }^{30}$ See discussion of reading under cxistimo, pp. 43, 44 . 
With pendere:

Ter. Hcaut. I 55 tu illum numquam ostendisti quanti penderes; Aug. De cura pro mort. ger. 7. 9; Oros. Hist. adv. pagan. v. I. 4.

With esse:

Plaut. Merc. 267; Capt. 145; Ter. Eun. 791 ; Ad. 977; Cic. Fam. vii. 19. I; vii. 29.1 ; xi. 27.3 ; xvi. 16. 2 ; Att. xiv. I 3 A fin.; Verr. iii. 72. 170; iii. 82.189; iii. 83. I9I; iii. 84. I95; iii. 85. 196; iv. 12. $28 ;$ Mur. 38 ; Fin.v. 6. 15; v. 29. 89; Rep. vi. 23. 25 ; N.D. iii. 3 1. 78 ; Cat. M. 14. 49; Sen. Ep. 90. 34; 11 5. 10; Ben. vi. 15. 4 ; Dig. iv. 2. 2 I. 2 ; ix. 2.2 quanti id in eo anno plurimi fuit, tantum aes dare domino damnas esto; xii. $3.8 ; x v .3 .4$.

With aestimare:

Cic. Att. ix. I 5. 5; xii. 47.2 quanti rem aestimas? Fam. iii. 9. I; x. 31.6; Ad Brut. i. I6. 5; Verr. iv. 7. I3; iv. 7. 14; Acad. ii. 38. 120; Tusc. i. 41. 98 ; v. 37 . I09; N.D. i. 20. 55 ; Paradox. vi. 3 . 5 I; Liv. xxix. I 7. I; Sen. Ben. vi. I5. 7; Q.N. i. prol. 16; iv. praef. 16; Ep. lxxiii. I1; Vit. Beat. 24. 5; Plin. H.N. xxxv. 8. 25; Tert. De pudic. 5.

With existimare:

Cic. Leg. agr. ii. $15 \cdot 40 .{ }^{3 \mathrm{t}}$

With habere:

Cic. Verr. iv. 9. I9 quanti auctoritas eius haberetur ignorabas?

With putare:

Cic. Verr. v. 9. 23 statuite quanti hoc putetis.

With valere:

Dig. ix. 2. 33 quanti omnibus valeret (servus).

With censere:

Plaut. Rud. I 272 dic ergo quanti censes; $C I L$ i. 198.57 quanti censuerint.

With indicare:

Plaut. Pers. 575 modo uti sciam quanti indicet.

With licere:

Cic. Att. xii. 23. 5 de Drusi hortis, quanti licuisse tu scribis.

With dedicare:

P. Africanus in Gell. vi (vii). I I. 9 tu in uno scorto maiorem pecuniam absumpsisti quam quanti omne instrumentum fundi Sabini in censum dedicavisti.

${ }^{31}$ See discussion of reading under existmare, p. 44. 
With taxare:

Sen. De ben. iv. 36. 2 quanti . . . verba taxentur; Ep. 8I. 8.

For quanto see p. 35 .

b) Boni consulere, aequi bonique facere, nithil pensi esse

As I have already pointed out (p. 2) these genitives are partitive in origin. Aliquid boni consulere means to consider something as forming part of that which is good; aliquid aequi bonique facere, to count something as a part of that which is fair and good; while in nihil pensi we have the same partitive genitive as in nihil mali, nihil novi.

\section{(I) Boni consulere}

That this was an old formula we know from Quintilian Inst. Orat. i. 6.32 sit enim 'consul' a consulendo vel a iudicando, nam et hoc 'consulere' veteres vocaverunt, unde adhuc remanet illud 'rogat boni consulas,' id est bonum iudices. Cf. also Paul. ex Fest. (Th. de P. 29. 3) 'consulas' antiqui ponebant non tantum pro 'consilium petas' et 'perconteris,' sed etiam pro 'iudices' et 'statuas.' It survived as an archaism, occurring sporadically in all periods of the language. An oldfashioned homely phrase, it is found most frequently in writings in which there is a tendency to use colloquial Latin, or where at least there is no effort made in the direction of an elevated style.

We find it first of all in Plaut. Truc. 429 boni consulas. Cato uses it, Orat. Reliq. (p. 4I Jordan) eane fieri bonis, bono genere gnatis, boni consulitis? and Varro L.L. 7. 4 M. potius boni consulendum quam ... reprehendendum. It occurs in Priap. 53. 6 consule poma boni, in familiar address to the least dignified of Italian deities, and in Ovid's pleading line, Trist. iv. I. 106 carmen, interdicta mihi, consule, Roma, boni. Cf. Ep. ex Pont. i. 3. 94 and iii. 8. 24. Augustus, a man of plain speech, makes use of it in his letter to Horace, Suet. de poetis (Reifferscheid, p. 47,8), libellum tuum, quen ego . . . boni consulo. Columella Io, praef. 5 says boni consulat, si non sit dedecori. It is a mannerism of Seneca: cf. Ep. I 7.7 id boni consulet; Ep. I 23. I hanc coqui ac pistoris moram boni consulo; Ben. i. 8. I; v. I 7. 5 ; vii. I. I; Prov. 2. 4 quicquid accidit boni consulant; Cons. Polyb. 10. 6. In all these instances it has a direct object. Less definite is Ben. ii. 2S. 2 hoc initium est: boni consulamus. With si clause, Ep. 75.6 sed si ita conpetit, ut . . . . , boni consulet; 88. I7 si quid remittitur, boni consulo; 107. 10. Other examples are: Plin. H.N. xxxiii prooem. 2. 4; i. I6. 44; Quintil. vi, prooem. I6 boni autem consulere nostrum laborem; Plin. 
Ep. vii. I 2. 3 quod si feceris, boni consulam. Apuleius, true to his archaizing tendency, shows some examples: Flor. 7 fin.; A pol. I6 med., with accusative and infinitive, ego non mirer, si boni consulis me de isto distortissimo vultu tuo dicere; 99 init. In Met. viii. 9 we have a development in the addition of the superlative: boni ergo et optimi consules, si . . . Met. vi. 3 is probably another example of the use of optimi, although in this case many of the MSS have optime. We find it again in its simple form in some of the later authors: Auson. Ep. I6. I (p. $175 \mathrm{Sch}$.) quod tu etsi lectum non probes, scriptum boni consules; and in a number of places in the letters of Symmachus, with accusative i. 20 (I5). 3 ut . . . has adlegationes boni consulas; i. 30 (24); iv. 58. I; viii. 49; with accusative and infinitive iii. I I. I deesse huic epistulae Atticam sanitatem boni consule; Dig. iv. 4 fin.; xxiii. 3. I2. I.

\section{(2) Aequi bonique facere}

This phrase is more distinctly colloquial. It occurs in Ter. Heaut. 788 ceterum equidem istud, Chremes, aequi bonique facio. Cf. Plaut. Mil. 784 aequi istuc facio, "that's all the same to me"; Cic. Att. vii. 7.4 qui totum istuc aequi boni facit; Liv. xxxiv. 22. $\mathrm{I}_{3}$ in a speech ceterum si . . . , nos aequi bonique facimus; Apul. Met. i. 5 init. istud quidem quod polliceris aequi bonique facio; Met. xi. I 8 oblationes honestas aequi bonique facio; Symm. Ep.i. $5^{\circ}(44)$. I.

\section{(3) Nihil pensi esse, habere, etc.}

Of the expressions in which pensi occurs, the earliest type is exemplified in Plaut. Truc. 765 nec mi adeost tantillum pensi iam quos capiam calceos. Of the same kind is Sall. C. 52. 34 quibus si quicquam unquam pensi fuisset; cf. Liv. xxvi. I5. 4 neque quid dicerent neque quid facerent quicquam unquam pensi fuisset; xxxiv. 3 I. 3 minus pensi esse; xxxiv. 49. 7 ; xlii. 22. 3 cui nihil pensi sit; xliii. 7. I I quibus nihil neque dicere pensi sit neque facere; Apoll. Sid. Ep. iii. I3; Greg. Hist. Franc. iv. $\mathrm{I} 2$ in Cautino autem nihil sancti, nihil pensi fuit.

In all these examples esse is the verb used. Nihil (nec quicquam) pensi habere is probably not much later in origin, although its first appearance in extant literature seems to be in one of the sententiae ascribed to Caecilius Balbus (p. 127 in Friedrich's edition of Publilius Syrus), nil pensi habere insanientem est vivere. Sallust uses it: C. 23.2 neque dicere neque facere quicquam pensi habebat; $5.6 ; 12.2$ linked with moderati: pudorem, impudicitiam . . . . nihil pensi neque moderati habere; J. 4I. 9 nihil pensi neque sancti habere; Sen. Ben. i. 9. 4; 
Suet. Ner. 34; Dom. I2. In Gell. xiii. I2. 2 we find a variation of the phrase in ratum pensumque nihil haberet, where the form of pensum is probably due to that of ratum. Lactantius, Div. inst. vi. I. 8, says nihil denique moderati aut pensi habent, dummodo . . . . , where the phraseology is very similar to that of Sallust $C$. I2. 2, cited above; Sulp. Sev. Chron. ii. 50. 2 certe Ithacium nihil pensi, nihil sancti habuisse.

So far, it will be observed, the genitive invariably depends upon some word or phrase such as nihil, nec quicquam, or mimus. Just when the freer type was developed, in which the genitive depends directly upon the verb, cannot be definitely ascertained. The first example is Val. Max. ii. 9. 3 nec pensi duxerat isdem imaginibus ascribi. This precedent is followed by Tacitus $A n n$. xiii. I4 neque fas neque fidem pensi haberet; Dial. 29 nec quisquam . . . . pensi habet quid. . . . . Cf. also Symm. Ep. i. $73(67)$; i. 75 (69) hunc ut pensi habeas; iii. I7. I ut in reliquum pensi habeas amicitiae diligentiam.

c) Magni preti, nullius momenti, etc.

See pp. 3-4; 9 .

\section{THE GENITIVE IN DEFINITE VALUATION}

Only a small number of examples have been found, and in the great majority of them esse is the verb used. Moreover the figures which are given in the money valuations are for the most part only approximate. This is seen clearly in the two examples from Cicero. The modifying vix in the passage of Petronius and puto in the example from Martial should also be noticed. Undoubtedly the regular case-usage in definite valuation is the ablative. See pp. $3 \mathrm{I}^{-} 32$.

a) In Money Valuations

Cic. Verr. i. 54. I 40 cum Habonio tutore, quod erat vix HS quadraginta milium, transigunt HS ducentis milibus; Off. iii. 23. 92 an emat denario, quod sit mille denarium? Petron. Cen. 30 vestimenta dispensatoris, quae vix fuissent decem sestertiorum; Mart. vii. 53. 9 vix puto triginta nummorum tota fuisse munera; Plin. Ep. vi. 3 (agellus) erat, cum donarem, centum milium nummum; Just. Inst. ii. 7. 2. dispositiones .... si maiores ducentorum fuerant solidorum.

$$
\text { b) Simpli, dupli }
$$

CIL i. I98. 59 eas res omnis simpli .... dupli (aestimari); Dig. xliii. 24. 7.4 simpli $^{32}$ litem aestimandam. Cf. Plaut. Poen. I 83 quid tu dubitas

${ }^{32}$ This is the reading of Mommsen. Schmidt reads simpliciter. 
quin extempulo dupli tibi, auri et hominis, fur leno siet? Cat. R.R. praef. furem dupli condemnare, faeneratorem quadrupli; Cic. Off. iii. I6. 65 dupli poenam subiret.

For the ablative duplo see p. 32 .

\section{THE GENITIVE IN EXPRESSIONS OF WORTHLESSNESS}

a) Nihili, flocci, nauci, etc.

\section{(I) Nihili}

Of all the expressions of worthlessness in Latin mitili, the genitive of nihilum (ne+hilum), is the one most frequently found. Unlike the others it is not confined strictly to the colloquial sphere. It has a wide range, showing greater mobility and more variety of use than any other. So frequent is it, and so common the occurrence of nithil and nihilo as colorless negatives, that its original meaning is almost lost sight of.

In hilum, its primitive, we have a word of somewhat doubtful etymology. Charisius, K. i. I02, quoting Varro, says "hilum Varro rerum humanarum intestinum dicit tenuissimum, quod alii hillum appellaverunt." Varro's own words L.L. v. 22. I I I (G. and S.) are $\mathrm{ab}$ eadem fartura farcimina $<$ in $>$ extis appellata, $\dagger$ a quo, in eo quod tenuissimum intestinum fartum, hila ab hilo dicta illo, quod ait Ennius 'neque dispendi facit hilum,' which he explains in ix. 37.54 as equivalent to 'nec dispendii facit quicquam.' Nonius (Lindsay, p. I 74) does not help us very much with his comment: hilum, breve quoddam. Lucilius (Marx IO2I): quod tu <nunc> laudes culpes, non proficis hilum. Perhaps the explanation of Festus (Th. de P. 72), hilum putavit esse quod grano fabae adhaeret, ex quo nihil et nihilum, brings us nearest to the ultimate force of the word. Modern etymologists connect it with filum, "a thread." See Stowasser, Lexikon, Vorbegriffe, $\$ 2$, and Walde, s.v. Besides the passages already cited it is used as something infinitely small by Lucilius ( $45^{8}$ Marx) hilo non rectius vivas; Plaut. Truc. 560 neque mea quidem opera umquam hilo minus propere quam pote[st] peribit. Cf. Lucret. iv. 5I5, where it occurs without a negative, libella aliqua si ex parti claudicat hilum; iii. 5 I4 aliquid prorsum de summa detrahere hilum.

With facere:

Nihili facerc, used absolutely, occurs in Plautus Merc. 439 illic pollicitust prior. Nihili facio; Capt. 616 nihili facio, tamen adibo; Bacch. 89 equidem 
pol nihili facio nisi causa tua; Cas. 605; 802. With accusative: Curc. 155 perspicio nihili meam vos gratiam facere; 2 I 8 qui me nihili faciat; Pseud. I I03 malus et nequamst homo qui nihili eri imperium sui servos facit. Cf. also Trin. 1032. With infinitive: Pers. 224 nihili facio scire; Pseud. I085 recte dicere qui nihili faciat. With dependent clause: Mil. I68 nihili facio quid illis faciat ceteris. Nihili fieri occurs in Stich. 637 viden ridiculos nihili fieri. Cf. Capt. 986. Cic. Fin. ii. 27. 88 eum (dolorem) nihili facit.

With pendere:

Nihili pendere is found in Plautus Most. 245 video te nihili pendere prae Philolache omnes homines; Poen. 520 nos te nihili pendimus; Trin. 607 me nihili pendere; Men. 993 nisi quidem vos vostra crura aut latera nihili penditis;

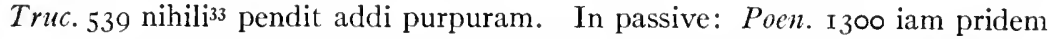
ego me sensi nihili pendier; Ter. Adelph. $45^{2}$ pater eius nili pendit; Eunuch. 94.

With esse:

Plaut. Most. I 56 nunc postquam nihili sum; Pscud. 239 ; Cist. 238 (twice). Cf. also Bacch. I 57 : PH. nihili sum. Ni. Istuc iam pridem scio, sed qui nihili’s, id memora; 91; I162; Cas. I 9; Truc. 553; Rud. 920 nimis homo nihilist; Pers. 96 nihilist macrum illud epicrocum pellucidum; Pseud. I I04; Bacch. I 207 hi senes nisi fuissent nihili iam inde ab adulescentia; Men. 972; Asin. 203 vetus est: "nihili coctiost"; Titin. ap. Fest. (Th. de P. 548. 8) quamquam est is nihili; Cic. Att. i. I 9. 4 ille alter nihili ita est, ut . . . . ; Tusc. iv. 35.74 illud .... ostendatur quam leve, quam contemnendum, quam nihili sit omnino; Apul. A pol. 42 init. argumentum .... futile et nihili futurum; 67; Lact. Divin. inst. i. I I. I6 qui sit et mortalis et imbecillus et nihili; vi. 22. I insipiens et ineptus et nihili est; Inst. epit. $48(53) \cdot 3$.

With aestimare:

Cic. Tusc. i. 8. 5 in a rendering of a saying of Epicharmus: emori nolo, sed me esse mortuum nihili aestimo.

With putare:

Cic. Sest. 53. i I4 ut conlegas . . . . bonorum iudicium nihili putaret; Apul. Apol. 23 init. si haec exempla nihili putas.

With reputare:

Cassian. Conlat. xvii. 20. I praesens illud dispendium .... nihili reputantes.

${ }^{33}$ This is the reading of Lindsay in the Oxford text; Spengel and Ussing also read nihili. The best manuscripts have mati, and on the basis of this Schöll has suggested

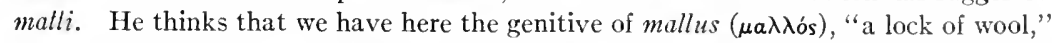
and compares Cat. De re rust. 157. This emendation, however, is ingenious rather than convincing. Leo gives in his text etiam num mali pendit, marking the passage as corrupt. He suggests etiam nummuli non pendit pattam. 
With deprehendere:

Auson. Technopaegn. 2. 5 cum sit aliquid, vel nihili deprehenditur.

For use of nihilo see p. 35; pro nihilo, p. 37. For examples of nihili used attributively see p. 9 .

\section{(2) Nulli}

Of this form (=nullius) I find only one example: Apul. Flor. ix (Oud. p. 36) gemmam et aurum iuxta plumbum et lapillos nulli aestimare. Burmann reads nihili, but his conjecture seems to be without justification.

\section{(3) Flocci}

In the use of flocci, the genitive of floccus "a flock of wool" (cf. Varr. R.R. ii. II. 8), the original meaning of the word is still felt. It differs from nihili also in the fact that it is not used attributively or with esse; it is found only with facere (its most frequent use), pendere, aestimare, and existumare.

As to the presence or absence of the negative, the examples of the former are much the more numerous, the proportion being about two to one. When used without a negative its exact force varies with the context. In some cases it means much the same as with a negative, as for example in Cato, Orat. Reliq. viii. 2 rumorem, famam flocci fecit, but in others it means to place a small but still some value on a person or thing. This may be illustrated by the passage in Terence, Eunuch 303, ut illum di deaeque senium perdant, qui me hodie remoratus est; meque adeo, qui restiterim; tum autem qui illum flocci fecerim, where Donatus remarks: nota flocci fecerim et contemnere et non contemnere significare, ut nunc. Compare the gloss given by Löwe, Glossae Nominum, p. I56, flocci pendere, alicuius momenti iudicare. Yet while this use of flocci facio is worth noticing, the difference between it and the more usual direct negative form is apparent rather than real. Taken with its context, it is but a variation of the negative form. For instance in the passage cited from the Eumuchus, "Perdition take me for having cared a straw for him," is only a strong way of saying, "I should not have cared a straw for him."

With facere:

Negative: Plaut. Truc. 606 non hercle ego te flocci facio; 769 de nihilo nihil est irasci, quae te non flocci facit; Curc. $713 ;$ Men. $423 ;$ Rud. 47 is leno ... . flocci non fecit fidem; $7 \delta_{2}$ ego quae tu loquere flocci non facio; Trin. 2I I non flocci faciunt, dum . . . 9 9 8 neque adeo edepol flocci facio, quando 
egomet memini mihi. Cf. Juventius (Ribb. Frag. ii. 82) pallium non facio

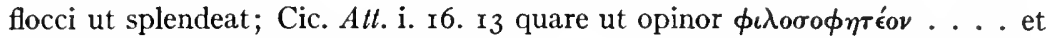
istos consulatus non flocci facteon; iv. I5. 4 totam denique rem publicam flocci non facere; xiii. 50. 3 prorsus aveo scire, nec tamen flocci facio.

Virtually negative: Plaut. Trin. 992 di me perdant si te flocci facio an periisses prius; Men. 994 cave quisquam quod illic minitetur vostrum flocci fecerit; Cas. 332 tu istos minutos cave deos flocci feceris; Stich. 285 cave quemquam flocci feceris; Most. 808 cave tu ullam flocci faxis mulierem; Ter. Eunuch. 303. Cf. also the following examples where there is no negative: Cat. Orat. Reliq. viii. 2 quoted above; Plaut. Epid. 348 dum tibi ego placeam ... . meum tergum flocci facio; Titin. ap. Non. (Lindsay, p. I9I), "lotiolente!" "flocci fiet."

\section{With pendere:}

Plaut. ap. Fulgent. De absir. serm. (Leo, II, 553) flocci dixerunt quasi nihili. Unde et Plautus ait: flocci pendo quid rerum geras; Ter. Eunuch. 4 II ego non flocci pendere.

\section{With aestimare:}

Plaut. in Paulus' Excerpts from Festus (Th. de P. I2I) neque muneralem legem neque lenoniam, rogata fuerit, necne, flocci aestimo. In this passage Scaliger on account of the meter changed aestimo, which is the reading of the codices, to existumo, and he has been followed by Lorenz, Winter, and Lindsay. Aestimo, however, is retained by Thewrewk de Ponor, Leo, and the editor of the Thesaurus Linguae Latinae.

With existumare:

Plaut. Most. 76 satin abiit, neque quod dixi flocci existumat?

For the use of the accusative floccum with interduim see p. 36 .

\section{(4) Nauci}

How early the original signification of nauci was lost may be seen from Plaut. Most. IO4I qui homo timidus erit in rebus dubiis, nauci non erit; i atque equidem quid id esse dicam verbum nauci, nescio. The number of explanations cited by Festus (Th. de P. I70) shows the great uncertainty of the grammarians as to its real meaning: naucum ait Ateius Philologus poni pro nugis. Cincius, quod in $\dagger$ olę . . . . nucisque intus sit. Aelius Stilo omnium rerum putamen. Glosematorum autem scriptores, fabae grani quod haereat in fabulo. Quidam ex Graeco, quod sit vai kai oúxi, levem hominem significari. Quidam nucis iugulandis, quam Verrius iugulandam vocat, medium velut dissepimentum. Charisius (K. i. 207), who treats it among the 
adverbs, says: nauci pro nihili te duco. Est autem fabae granum, cum se aperit. It is probably to be connected with nux, as some of the grammarians cited above and modern etymologists suggest. See Stowasser and Georges s.v.

The examples are scattered and rare. In addition to the passage in the Mostellaria cited above Plautus uses it in a fragment quoted by Festus (loc. cit.): ambo sumus non nauci; and in two other places (see p. 9) he employs it attributively. In Ennius Sat. (B 494) non nauci est homo. In Cicero Div. i. 58. I32 non habeo denique nauci Marsum augurem. A fragment of Gavius Bassus (ap. Fulgent. Expos. Serm. antiq. 564. 2I) shows its use with facere: veruina confodiende, non te nauci facio. Apuleius Apol. 9I combines it with putare: quid illi existument, nauci non putabo, where the best codices have nacci. Ausonius Cent. Nupt. I. 5 speaks of it as a favorite word with Afranius: neque Afranius naucum daret. In all these cases it is used with a negative.

For nauco see p. 36 .

\section{(5) Hettae}

For our knowledge of this colloquialism we are indebted to Festus (Th. de P. 7I), who alone has preserved it: hetta res minimi pretii, quasi hieta, id est hiatus hominis atque oscitatio. Alii pusulam dixerunt esse, quae in coquendo pane solet adsurgere, a quo accipi rem nullius pretii, cum dicimus "non hettae te facio." With the last explanation cf.

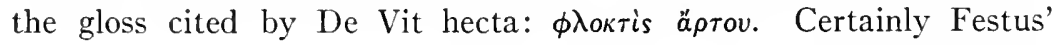
etymology is not very probable, and the same may be said of Lewis and Short's suggestion that it may be kindred with $\ddot{\eta} \tau \tau \omega \nu, \ddot{\eta} \sigma \sigma \omega \nu$.

\section{(6) Pili}

This expression occurs in Catull. Io. I3 non faceret pili cohortem; 17. I7 ludere hanc sinit ut lubet, nec pili facit uni; and in Petron. Cen.

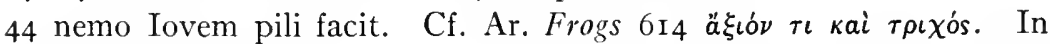
expressions other than those of valuation we find in Cicero $Q . f r$. ii. 15. 5 ego enim ne pilo quidem minus te amabo; Att. v. 20. 6 interea e Cappadocia ne pilum quidem.

\section{b) Coins}

Coins of small value are not infrequently used as expressions of worthlessness. We find examples of sescunciae, sextantis, terunci, semissis, assis, dupondii, tressis, and trioboli.

Wölfflin in Archiv, IX, 105, draws attention to the gradual increase from terunci of Plautus and sescunciae of Pomponius to dupondii of 
Petronius and tressis of Persius through the intermediate stages of semissis and assis, this being connected with a corresponding depreciation in the value of the as. The lines, however, should not be drawn too strictly. The as was proverbial as early as Cato's time and occurs in Seneca; semissis is found in Cicero's correspondence as well as in Lucilius, and sextantis occurs in Cicero.

Some of these genitives are, as we have seen, attributive: senica non sescunciae, servus sextantis, non homo trioboli. Sextantis in the passage in Cicero is used predicatively with esse. Of the rest the majority are combined with facere. The only example of aestimare is in Catullus. It is almost always the negative that is used.

See p. 9.

\section{(I) Sescunciae}

\section{(2) Sextantis}

Cic. De orat. ii. 62. 254 tuus amicus .... non esse sextantis; see also p. IO.

\section{(3) Terunci}

Plaut. Capt. 477 neque ridiculos iam terunci faciunt. For Cicero's use of teruncius to denote an infinitely small sum, cf. Att. v. I7. 2 nullus teruncius insumatur in quemquam; v. 20. 6; v. 2 1. 5 ; vi. 2.4 ; Fam. ii. 17. 4 ; Fin. iii. 14. 45 ; iv. 12. 29. In none of these cases in Cicero is a verb of rating used. Cf. libella in Plaut. Pseud. 628; nummus ... . plumbeus, Cas. $25^{8}$.

\section{(4) Semissis}

See p. זо.

\section{(5) Assis}

Catull. 5.3 rumores omnes unius aestimemus assis; 42.13 non assis facis? O lutum, lupanar; Carm. Priap. 8. 3 non assis faciunt euntque recta; Hor. Sat. i. 6. I3 unius assis non unquam pretio pluris licuisse; Sen. Ep. I23. I I istos tristes et superciliosos alienae vitae censores .... assis ne feceris. Here may be noted Bücheler's suggestion to read in Sen. A pocoloc. I I tris homines assarios instead of the traditional Tristionias, Assarionem.

For the use of asse and sestertio nummo see p. $3^{6}$.

\section{(6) Dupondii}

Petron. Cen. $5^{8}$ matrem meam dupundii non facio; $5^{8}$ fin. nemo dupondii evadit. Cf. also in the same chapter dominus dupunduarius; 74 homo dipundiarius. In Hieronymus Adv. Helvid. I6 dupondii turns up with supputare: quis te, oro, quis dupondii supputabat. An example showing the antiquity of 
the belief that a freshman is a fair mark for ridicule is furnished by the application of the term dupondius to the first-year students in the law schools of the time of Justinian. We find Justinian gravely prohibiting its use in the second section of the letter addressed to Theophilus and others at the beginning of the Digest: cuius (anni primi) auditores non volumus vetere tam frivolo quam ridiculo cognomine dupondios appellari, sed Justinianeos novos nuncupari.

\section{(7) Tressis}

See p. ı.

\section{(8) Trioboli}

See p. Io.

c) Huius (accompanied by a gesture)

Sometimes a gesture, a snapping of the fingers or something of the kind, is used in the contemptuous rating of a person or thing: Ter. $A d$. 163 tu quod te posterius purges, hanc iniuriam mihi nolle factam

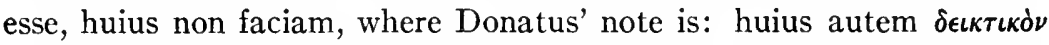
est. Aut enim stipulam aut floccum moverat, aut summum digitum. For a similar use of tanti see p. I6. 


\section{THE ABLATIVE WITH VERBS OF RATING}

\section{THE ORIGIN OF THE CONSTRUCTION}

Instead of the genitive, the ablative is found with verbs of rating in a considerable number of examples. These include both definite and indefinite valuations. The employment of this case, as is generally recognized, is due to the influence of the regular use of the ablative with verbs of buying and selling, which is in origin instrumental. That the case-usage with verbs of rating should be influenced by a construction which is so close to it as this is not surprising. And it is significant that it is in the expression of definite valuation (which obviously approaches the idea of buying and selling more closely than any other) that the use of the ablative is most constant. When a definite price has been put upon a thing, it is fairly within the sphere of barter, and quite naturally its valuation is expressed in terms of barter and exchange. Furthermore, additional confirmation of the theory that the ablative of value is the result of influence by the ablative of price is found in the fact that the great majority of all the examples of the ablative with verbs of rating occur with aestimare. This, more than any of the other verbs of rating, is the sober business term, and by reason of its connotation of exact valuation is likely to be more sensitive to the influence of the verbs of buying and selling. It is noticeable, however, that the number of ablatives of value occurring in the early period is very small. My lists show only four that are earlier than Caesar: one in Naevius, two in Plautus, and one in Lucilius.

\section{THE ABLATIVE IN DEFINITE VALUATION}

In his article, "34 "Der Genetiv des Wertes und der Ablativ des Preises," Wölfflin says: "Dass der Unterschied [i.e., between the ablative and the genitive] nicht darin liegt, ob die Wertangabe eine bestimmte oder eine unbestimmte sei, beweist ja Cic. De off. iii. 23. 92 deutlich genug, indem er schreibt: an emat denario, quod sit mille denarium?" And Bennet ${ }^{35}$ in commenting on the close relations between the genitive of value and the ablative of price remarks: "The distinction sometimes made that the genitive is used to denote indefinite price, the ablative

${ }^{34}$ Archiv fiur lateinische Lexikographie und Grammatik, IX, I02.

${ }^{35}$ Syntax of Early Latin, II, 97. 
definite price, will not hold at all." But so far as the verbs of rating are concerned, the distinction does hold to the extent that the ablative is the regular case for the expression of definite valuation, even though the genitive is sometimes used.

\section{a) In Money Valuations}

Plaut. Capt. $3_{4} 4$ nam ego te huic dedi aestumatum viginti minis; 438 minis viginti aestumatum; Lucil. (Marx 499) in pretio: primus semisse, secundus nummo, tertius iam pluris quam totus medimnus; Sall. fragm. Hist. iii. 48. I9 quinis modis libertatem omnium aestimavere; Nep. Timoth. 3.5 lisque eius aestimatur centum talentis; Mil. 7. 6 lis quinquaginta talentis aestimata est; Cic. Verr. iii. 8I. I 88 modios singulos ternis denariis aestimavit; iii. 8I. I89 cum in Sicilia HS binis tritici modius esset, summum HS ternis, iste pro tritici modiis singulis denarios ternos ab aratoribus exegit; iii. 84. I94 cum esset HS binis aut etiam ternis; iii. 85. 196 video (frumentum) esse binis HS; iii. 92. 2I4 aestimavit denariis III; iii. 94. 220 ternis denariis aestimare; iv. 7 . I3 si denariis quadringentis Cupidinem illum putasset; v. 32. 83 ternis denariis aestimatum frumentum; Div. Caec. Iо. 3 o cum esset tritici modius sestertiis duobus; Liv. iv. I6. 2 frumentum Maelianum assibus in modios aestimatum; xxi. 4I. 6 duodevicenis denariis aestimatos; xxii. 59. I 8 redeam ego in patriam trecentis nummis non aestimatus civis? xxix. 37.3 sextante sal . . . erat; Sen. Ep. 95. 59 sestertio nummo aestimanda sunt; Petron. Cen. 65 quinquaginta enim millibus aestimant mortuum; Plin. H.N. xxxiii. I3. 163 quinis assibus aestumatum; xxxv. 6. 47 trecenis nummis taxari; xxxv. 6. 48 aestimatum sestertiis in libras; xxxv. 10. 70 quam picturam .... HS $|\mathrm{LX}|$ aestimatam cubiculo suo inclusit; xxxvii. 6.82 sestertio vicies aestimatum; Tac. Ann. i. 17. I 2 denis in diem assibus animam et corpus aestimari; Fest. (Th. de P. 242. I 7) boves centenis assibus, oves denis aestimatae.

\section{b) Duplo}

Dig. xlvii 2. 27. I. an aestimari duplo chirographi quantitas debeat; xlvii. 2. 75 (74) duplo, quanti eius interest, aestimari debet.

\section{THE ABLATIVE IN INDEFINITE VALUATION}

a) Pretio, aere, momento, etc.

\section{(I) Pretio}

Val. Max. v. 4. I magno ubique pretio virtus aestimatur; Sen. Ep. 66. I I non eodem pretio aestimantur; Ben. ii. 26 nec satis suo pretio se aestimatum putet; Prov. 3. 9 hoc pretio aestimasse virtutem; Tac. Ann. xi. 26. 5 veris ... pretiis aestimaret; Gell. ii. 23. 7 non dispari magis pretio aestimata sunt; Fronto (N. 238) secundo rumore populi florere pretioque esse; Apul. A pol. 97 quam magno pretio computarat; Arnob. Adv. nat. ii. 29 immanibus 
pretiis aestimare; vi. 3 ea pretiis carioribus penditis; Lactant. Div. inst. vi. I I. 16 iustitiam .... suo pretio aestima; Symm. Ep. ix. 93 parvum, si aestimatur pretio sui; Dig. viii. 2. 23. 3 pretioque eo aestimandum, quanti fuit; x. 3. 7. I 2 ut non vero pretio aestimetur pars; x. 3. ro. I 2 iusto pretio rem aestimare; 24. I. 36 aestimatio facienda est iusto pretio.

\section{(2) Aere}

Sen. Ep. 87. I 7 virtus . . . . suo aere censetur; Paul. ex Fest. (Th. de P. r8) qui (antiqui) eam (poenam) aestimaverunt aere.

\section{(3) Summa}

Gell. 6 (7). 13. 2 qui minore summa aeris . . . . censebantur.

\section{(4) Momento}

Caes. B.G. vii. 39 levi momento aestimare; Cic. De invent. ii. 26. 77 magno ad persuadendum momento futurus sit; Font. ro. 2 I ad unam quamque rem existimandam momentoque suo ponderandam.

\section{(5) Vita}

Curt. v. 5. 18 quidquid homines vita aestimant, "value as highly as life."

\section{(6) Contubernio}

Tac. Agr. 5 electus (Agricola) quem contubernio aestimaret (Suetonius Paulinus).$^{36}$

${ }^{36}$ Related to the examples of indefinite valuation given under (1), (2), (3), (4), $(5),(6)$ is the use of the ablative to express the standard of valuation. Cf. Hor. $E p$. ii. r. 48 virtutem aestimat annis; Liv. iv. 54.6 quaesturamque eam non honoris ipsius fine aestimabant sed ... . ; vii. 32. 7 ne Sidicinorum Campanorumque cladibus Samnitium aestimarent virtutem; xxii. 8. 4; xxix. 26. 2; Col. x praef. 2 non naturalibus desideriis sed censibus aestimentur; Sen. Ep. 45. 9 qui hominem ea sola parte aestimat, qua homo est; 76. 32; Just. 30. 4 nec Macedones veteri fama sed praesentibus viribus aestimandos; Tac. Hist. iv. 73 bonaque ac mala non sua natura, sed vocibus seditiosorum aestimantur; Lact. Div. inst. vi. I I. 16 iustitiam . . . . non tuo commodo aestima; Symm. Ep. viii. 93 religiosum, si amore pendatur. Cf. the similar use of the ablative with censeo: Plin. Pan. I5. 5 quisquis paulo vetustior miles, hic te commilitone censetur; Suet. Gramm. ro Eratosthenes multiplici variaque doctrina censebatur; Val. Max viii. 7. ext. 4 cum divitiis censeri posset; Orient. Carm. app. 2. 154 propriis meritis tanti censentur honores. This use of the simple ablative encroaches upon the field of $e x$ and the ablative which Cicero uses in Rosc. Com. 10. 29 ex veritate pauca, ex opinione multa aestimat; Caes. B.G. iii. 20 cum in Aquitaniam pervenisset, quae pars ex tertia parte Galliae est aestimanda, i.e., is to be reckoned as a third part; Sall. Cat. 10. 5 amicitias inimicitiasque non ex re sed ex commodo aestumare. Cf. Cic. Paradox. vi. I. 44 ex eo, quantum cuique satis est, metiuntur homines divitiarum modum; Part. Or. 34 . I I 7 dicendum erit non esse ex fortuna fidem ponderandam; Quinct 1.5 si ex opibus, non ex veritate causa pendetur; Fam. v. 17. 5 te non ex fortuna sed ex virtute tua pendimus semperque pendemus. Though used less frequently $e x$ still persists: cf. Arnobius Adv. nat. ii. 49 genus 
b) Magno, parvo, etc.

(I) Magno

With esse:

Sen. Ben. vii. 9. 3 luxuria magno fuerit.

With aestimare:

Cic. Fin. iii. 3. II ; v. 30. 90 ; Tusc. iii. 4. S; Paradox, vi. 3.51 ; Verr. iv. 7. 13 (permagno); Liv. xl. 55. 3 magno te aestimaturum, si . . . ; xli. 20. 3 ; Sen. Ep. 104. 34; Cons. Helv. 16. 6; Bres. Vit. 7. 8; Tranq. I. I1; Vit. Beat. 14. 3 ; Ira ii. 36.6 ; iii. 3 I. 3 ; iii. 34.2 ; Ben. iv. 6.3 ; v. 3. I; vi. 33.3 ; Q.N. ii. 59. 7 ; iii. praef. 13; Plin. Pan. 37; Suet. Calig. 39; Paul. Nol. Epist.xxiii. 34.

\section{(2) Maiore}

With valere:

Cod. Iust. ii. I9 (20). 5 possessiones suas quae maiore valebant.

\section{(3) Plure}

While no well-attested example ${ }^{37}$ of plure with a verb of rating has been found, the form, according to Charisius (K. i. I09. Io), was used with verbs of buying and selling: plure aut minore emptum antiqui dicebant: Cicero "plure venit," et Lucilius "plure foras vendunt." Sed consuetudo pluris et minoris dicit. And on p. 211. 27 the same grammarian gives an example from Plautus: plure Plautus in Caeco vel in Praedonibus: "plure altero tanto quanto eius fundus est velim."

\section{(4) Parvo}

With aestimare:

Sen. Ben. i. 8. 2; Ira iii. 31. 3; Ep. 104. 34; Lact. Div. inst. iii. 25.

\section{(5) Minore}

With taxare:

Fest. 322. 12 (Th. de P.) minore . . . . taxat.

humanum non ex bonis pauculis sed ex ceteris omnibus aestimari convenit et ponderari. We find also de and the ablative with censere: Tert. adv. Marc. i. 8 divinitas nec de novitate nec de vetustate, sed de sua veritate censetur; i. 25. In Tac. Agric. 40 fin. the standard of valuation is expressed by per and the accusative: quibus magnos viros per ambitionem aestimare mos est, the only example of the kind according to Dräger. It is not, however, essentially different from the familiar per se as used in Liv. xxii. 8. 3 non id, quod acciderat, per se aestimare.

${ }_{37}$ See p. 13 , footnote 27. 


\section{(6) Minimo}

With aestimare:

Cic. Verr. iii. 95. 22 I stultissimus quisque posthac minimo iestumabit.

With valere:

Dig. xix. I. I3. 5 quasi minimo valeret hereditas.

\section{(7) Quanto-Tanto}

With valere-aestimare:

Vulg. Levit. 27. 17 quanto valere potest, tanto aestimabitur (ager).

(8) Quanto

With facere:

Sen. Ep. 85. I2 tantique erunt quanto fient.

With esse:

Plaut. in Charisius (K. i. 2I I. 28) quanto eius fundus est.

With aestimare:

Sen. $\operatorname{Ira}$ iii. 32. 2 tunc videbimus quanto ista lis aestimanda sit; Symm. Ep. ix. I 77 habes in manu, quanto aestimare mihi debeas.

With aestimare:

\section{(9) Quantocumque}

Vulg. Levit. 27.27 quantocumque a te fuerit aestimatum (animal).

$$
\text { (ro) Vili, Caro }
$$

With aestimare:

Paulin. Nol. Ep. xxiii. 34 qui ipsum vili aestimans dominum, unguentum ... . caro aestimavit; and in the same paragraph, a few lines below: se vili vult aestimari.

With esse:

\section{(I I) Vilissimo}

Dig. xxiv. I. 7.3 praedia hodie vilissimo sunt.

\section{THE ABLATIVE IN EXPRESSIONS OF WORTHLESSNESS}

a) Nihilo, etc.

\section{(I) Nihilo}

With aestimare:

Cic. Fin. iv. 23.62 nec quia bonum sit valere, sed quia sit non nihilo aestimandum; Sen. Const. I3. 2 honores eorum nihilo aestimat. 


\section{(2) Nauco}

In a fragment of Naevius quoted by Festus (Th. de P. 170) we find eius noctem nauco ducere, the earliest example of this word in an expression of worthlessness. In view of the fact that the genitive nauci appears in all the other examples, and that the genitive is the case almost always used in this group of expressions (flocci, etc.), there is a possibility that the emendation to nauci made by Bothe and adopted by Lorenz is correct. The MSS, however, have nauco, which is retained by Ribbeck and Thewrewk de Ponor.

With the use of nauco may be compared that of muce in Plaut. Mil. 316 non ego tuam empsim vitam vitiosa nuce, and in Hor. Sat. ii. 5. 35 eripiet quivis oculos citius mihi quam te contemptum cassa nuce pauperet.

\section{b) Coins}

\section{(I) Asse}

Cat. ap. Sen. Ep. 94.27 quod non opus est, asse carum est. Cf. Stat. Silv. iv. 9. 22 emptum plus minus asse Gaiano, where there is a reference to the decreased value of the as in the time of Caligula.

\section{(2) Sestertio nummo}

Sen. Ep. 95.59 divitiae, gratia, potentia sestertio nummo aestimanda sunt. Petronius Cen. 45 has sestertiarius homo and in the same chapter gladiatores sestertiarios iam decrepitos. ${ }^{38}$

${ }^{38}$ Expressions of worthlessness occur with other verbs than those of rating and in other cases than the genitive and ablative. For example we find the accusative floccum in Plaut. Trin. 994 qui sis, qui non sis floccum non interduim. Ritschl reads ciccum here on the ground that floccum would not be used so soon after flocci of v. 992 . But there seems to be no justification for the change. Brix, Leo, Lindsay, and other editors retain floccum. Ciccum, however, occurs in other passages of Plautus. It is properly the thin membrane surrounding the grains of the pomegranate. Cf. Varr. L.L. vii. 9 I ciccum dicebant membranam tenuem, quae est ut in malo Punico discrimen; Paul. ex Fest. (Th. de P. 30) membrana tenuis malorum Punicorum. In Corp. Glossar. Lat. ii. $100 \gamma \rho \hat{v}$ and ко́ккоs are given as Greek equivalents. As regards the form of the word the evidence of the glossaries and of the MSS of Plautus favors ciccum. Lewis and Short give ciccus on account of the Greek кіккоs, but the latter is an extremely doubtful word, being only an emendation by Schneider of кєккаios of Hesychius. The Thesaurus has ciccum. It is a rare word. The only instances noted are in Plautus, and even there, in spite of Ausonius' remark (Cent. nupt. I. 5) "neque ciccum suum Plautus offerret," there seem to be only three well-attested examples: Rud. 580 eluas tu an exunguare, ciccum non interduim; fragm. ap. Varr. (Leo. ii. p. 542) quod volt det pensum, ciccum non interduo.

Ptuma occurs in Plaut. Most. 407 pluma haud interest, patronus an cliens probior siet. Cf. Men. 488 quid ais, homo levior quam pluma, pessume et nequissime. Alga 


\section{THE ABLATIVE WITH A PREPOSITION}

a) Pro

With a number of verbs of rating pro with the ablative is used instead of the genitive of value. This is, ultimately, a development of the use of pro with the force of 'in the place of,' 'instead of,' 'for,' seen in such examples as Cato (Jordan, p. 37. 16) numquam ego argentum pro vino congiario .... disdidi. Of the intermediate stages in the development one is to be found in the occurrence of pro in expressions of price. Cf. Plaut. Most. 823 tris minas pro istis duobus .... dedi. Another is its use with verbs of viewing, judging, considering, etc. Cf. Plaut. Stich. 57 I sese ducit pro adulescentulo; Ter. $A d .48$ hunc . . . . habui, amavi pro meo; Cic. Verr. ii. 4. 33; and the frequent occurrence of pro certo habere and similar expressions, as in Cic. Att.x. 6. 3 Pompeium pro certo habemus per Illyricum proficisci in Galliam; Sall. C. 52. I7; Liv. xxiii. 6. 8; xxv. I0. I. Many examples of this usage might be given. It emerges at an early period and maintains itself throughout the history of the language.

\section{(I) In Expressions of Worthlessness}

(a) Pro nihilo

This phrase is rare in early Latin. It occurs, however, in Caecil. ap. Varr. L.L. vii. Io3 (Spengel). It is fully developed in Cicero who, apparently on rhetorical grounds, prefers it to nihili in those writings in which he pays special attention to style. Of nihili there seem to be only five examples in all his works; of pro nihilo, on the other hand, some thirty have been noted, seventeen of which occur in the philosophical writings, eleven in the speeches, two in the letters. The

is used in Hor. Sat. ii. 5. 8 et genus et virtus nisi cum re vilior alga est; and in Verg. Ecl. 7.42 proiecta vilior alga.

With these expressions of worthlessness should be contrasted the use of standards of value: e.g., aurum, which is relatively frequent: Catull. 107. 3 quare hoc est gratum, nobis quoque carius auro, quod te restituis, Lesbia, mi cupido; Ov. A.A. 2. 299 auratast; ipso tibi sit pretiosior auro; $A$ m. iii. 8.3 ingenium quondam fuerat pretiosius auro; Met.8. 79 illa mihi est auro pretiosior; Claud. Bell. Goth. 607 pretiosior auro sanguis erat; Aug. Contr. mend. iii. 5 multis librarum auri milibus pretiosiorem. Cf. Contr. Adimant. I9 (sapientia) pretiosior est autem Iapidibus optimis; Lucif. Moriend. I5 (Vulg. Ps. I8. I I. I2) desiderabilia enim super aurum et lapidem pretiosum multum. Vita is also used, Luc. v. 739 vita non nunc mihi dulcior. Lutx occurs in Claud. Bell. Goth. 308 hic carior omni luce gener. 
statistics are significant. The phrase, well adapted to the fuller style of the philosophical works, is not in keeping with the conciseness and brevity of the letters.

In almost every case it occurs in the cadence of the sentence, and in a large number of examples it stands as the last member of a climax. In this, which is perhaps its characteristic position, the stylistic effect is most clearly seen. Cf. Fin. i. 32. 6I quam contemnet, quam despiciet, quam pro nihilo putabit; Tusc. iii. I 7. 36 ut omnia ... contemnas et pro nihilo putes; Off. i. 9. 28 contemnant et pro nihilo putent; $D_{e} O r$. ii. 84. 344 magnitudo animi, qua omnes res humanae tenues ac pro nihilo putantur; Mil. 24.64 ut . . . . contempsit ac pro nihilo putavit! Div. in Caecil. 7. 24 contempsit semper ac pro nihilo putavit; Fin. iii. 8. 29 despicere ac pro nihilo putare; iii. I I. 37 non requirat et pro nihilo putet? Vatin. 9. 23 solus conculcaris ac pro nihilo putaris; Fin. iv. I4. 37 relinquat et pro nihilo habeat herbam; Off. iii. 5. 24 contemnere et pro nihilo ducere; Tusc. v. IO. 30 opes contemnere eaque ... pro nihilo ducere.

Elsewhere it is used alone: Cf. Phil. ii. 23. 56 quoniam condemnatum esse pro nihilo est; Att. xiv. 9. I di immortales, quam mihi ista pro nihilo! Fin. ii. I3. 43 quae . . . visa sunt pro nihilo; Phil. i. 6. I4 ut . . . rempublicam pro nihilo haberemus; Dom. I4. 38; Tusc. v. 26. 73 quam pro nihilo puto! Fin. v. 24.72; Lacl. 23.86; Phil.x. 3.6; Fam.x. 26.3; Tusc. v. 32. 90 pro nihilo pecuniam ducere; Verr. ii. I6. 40.

Other examples of pro nihilo occur here and there in classical and silver Latin. Cf. Sall. J. 3I. 25 quae .... pro nihilo habentur; Liv. ii. 6r. 5 tribunos . . . . pro nihilo habebat; xxxiii. 46.3; Sen. Cons. Polyb. Iо. 3 habuisse eadem pro nihilo ducit; Q.N. iv. I 3 . Io pro nihilo est familiaris rigor; Pers. I. 30 ten' cirratorum centum dictata fuisse pro nihilo pendas? Sil. Ital. ii. 494 pro nihilo esse; Plin. H.N. xviii. 3I. 3 I 9.

In later Latin we find it taken up by some of the Church Fathers. Cf. Lact. Inst. epit. 47 (52). I philosophiam. . . . pro nihilo computent; Sulp. Sev. Append. Ep. 2. 2. Lucifer uses it in several passages: De sanct. Athanas. i. 24; ii. I 7 dignaris pro nihilo habere persequi servos unici filii dei; Moriend. 4 ; De reg. apost. 4 haec omnia ducens pro nihilo; 7 ; De sanct. Athanas. i. 38; De non parcendo I7: Moriend. 4 (twice). Cf. Paul. Nol. Append. Ep. 2. 3 qui autem pro nihilo me habent, ad nihilum redigentur; 2. 4; Dig. xix. 2. 25 tunc pro nihilo esse conductionem quasi nulla mercede statuta; xxviii. 4. I; Gregory of Tours, Lib. vit. patr. x. (2), says oblectamenta pro nihilo reputata; xiii init. contumelias pro nihilo habuerunt; and, what is of 
special interest, shows examples of the combination of pro nihilo with verbs other than those of rating, namely respuere and deducere. The same thing occurs in Orosius $A d v$. pagan vi. I. I6 with contemnere: et ipsi pro nihilo contempti sunt. This development is in direct line with the Ciceronian phraseology already pointed out, e.g., Tusc. iii. I 7. 36 contemnas et pro nihilo putes; Fin. iii. I I. 37 respuat .... et pro nihilo putet.

\section{(b) Pro nullo}

This seems to occur only in late authors: Salvianus, De gubern. dei iv. 2. 7 pro nullo hoc habendum existimaret; Dig. ii. 2. 1. 2 quoniam pro nullo hoc habetur; xxviii. 8. I quia pro nullo isti habentur apud praetorem.

\section{(c) Pro luto}

This is found in Petronius with esse and habere; Cen. 44 pro luto erat annona; $5 \mathrm{I}$ quia enim, si scitum esset, aurum pro luto haberemus; 67 omnia pro luto haberemus. Cf. Aug. Contr. Adimant. I 9 tamquam lutum aestimabitur argentum, a rendering of the Book of Wisdom vii. 9 .

\section{(2) In Indefinite Valuation}

(a) Pro pretio

Auson. Ep. 14. 20 sit tibi pro pretio.

\section{(b) Pro magno aere}

Symm. Ep. v. 49 pro magno aere censeri.

(c) Pro magno

Aug. De ag. Christ. I3. I4 pro magno habere; De bono viduitatis xxii. 27 non laudem hominum pro magno sumebat apostolus; Greg. Hist. Franc. ix. 3 I pro magno ducentes si vel vitae donarentur.

(3) In Definite Valuation

(a) In Money Valuation

Liv. xxxviii. II. 8 dum pro argenteis decem aureus unus valeret.

(b) Pro oculo, pro dente

Tert. Adv. marc. iv. 16 quomodo "oculum pro oculo" et "dentem pro dente" censuerit. 
b) $I n$

(I) In pretio

$I n$ is most frequently found with pretio: Liv. xxxix. 6.9 tum coquus, vilissimum antiquis mancipium et aestimatione et usu, in pretio esse; in the Fasti of Ovid in many passages: i. $2 \mathrm{I} 7$ in pretio pretium nunc est; iv. 405 aes erat in pretio; v. $5^{8}$ inque suo pretio ruga senilis erat; v. 3 I 6 nec in pretio fertilis hortus erat; vi. 33; vi. I 79; Sen. Ep. 75 . I in magno pretio habere in aliquo habenda vel in nullo; I23. I 6 in nullo habenda pretio; Ben. i. 6. 2; vii. Io. I omnia ista quae retuli in maiore honore pretioque sunt; Cons. Marc. I. 3 ; frequently in Plin. H.N. vi. 22 (24). 89 aurum argentumque et ibi in pretio; xii. I2. 4I radix et folium Indis in maximo pretio; xii. 26. I 29 ; xvi. 4. I4; xvi. 43. $23 \mathrm{I}$; xix. 8. 152 ; $\mathrm{xxxi}$. 8. 94 nec liquor ullus paene praeter unguenta maiore in pretio esse coepit; xxxiii. (2). 4; xxxiii. 1. 22; xxxvii. 2. 2 I; Tac. Germ. 5; Apul. A pol. 23 arbor .... tanti est in pretio, quanti lignum eius in trunco; Lact. Div. inst. vi. 25. 4; Paul. Nol. Ep. xxii. 34.

(2) In lucro, in damno

In lucro esse occurs in Ov. Trist. I. 3. 68. Cf. Paul. Nol. Ep. xiii. I 5 damnum in lucro et in damno lucrum ducimus.

\section{(3) In pondere}

In pondere esse is found in Plin. H.N. xxxvii. 28. Arnob. Adv. nat. ii. 55 makes use of a unique phrase: nec in magnis ponderibus ducimus vel ignorare istud vel scire.

\section{c) Cum}

Only a few examples of the use of $\mathrm{cum}$ in expressions of valuation are forthcoming: Juv. iii. I 83 omnia Romae cum pretio; Auson. Technopaeg. 14. 2 nequam cum pretio est. 


\section{ADVERBS IVITH VERBS OF RATING}

An adverb, or word used as an adverb (like multum, nihil, plus), is sometimes found with a verb of rating instead of the genitive or ablative:

Care, Brut. Ep. i. I6. 6 valde care aestimas tot annos; carius, Planc. Fam. x. 4. 2 propter amorem carius sunt aestimata; Sen. Ep. 81. 28; Apul. Flor. I8 libri mei . . . . carius censentur; Aug. De duab. animab. 7 .

Graviter with censeo, Salv. Ad eccl. iv. 4I; gravius, Caes. Bell. Gall. vii. I4. Io multo illa gravius aestimare; Tac. Ann. xiii. 42.

Humiliter with aestimare, Val. Max. ii. 7. I4.

Iuxta, Sall. Cat. 2. 8 eorum ego vitam mortemque iuxta aestimo.

Levius, Caes. Bell. civ. iii. 26. 4. levius tempestatis quam classis periculum aestimaverunt.

Multum, Nep. Con. 2. I apud quem ut multum gratia valeret; with facere, Dig. xiv. 3. 3; xvi. r. 6 ; xviii. 7. 4 .

Nihil with facere, Lucif. De reg. apost. 7 hunc alienigenam fecit nihil ante Israel deus; Salvian. Ad eccles. iv. I. 2 sensus aut parvi aestimandi sunt aut nihil omnino faciendi.

Pensius with aestimare, Symm. Ep. I. 34 (28). 2.

Plus, Cassian. Inst. iv. 27. 2 utrum plus faceret affectionem sanguinis . . . . an oboedientiam; Contr. Nestor. vi. 5. I; Lucif. De sanct. Athanas. ii. 29; Dig. x. 3. 10. I.

Tenuissime with aestimare, Cic. Verr. iv. I6. 35 .

Vilius, with aestimare, Sen. Ep. 8r. 28; Aug. De duab. animab. 7; Salv. Ad eccl. i. I2. 6r. 


\section{THE VERBS OF RATING}

\section{Aestimare}

There are but few examples of the use of aestimare with a genitive of value in early Latin. Landgraf, Literaturnachweise 68, limits it to the tragic fragment quoted by Cicero De imvent. i. 45.83 qui id parvi auditum aestimet and the Lex repetund. vii quanti aestumata erit. There is, however, an example in Plautus, namely, the fragment in Paul. ex Fest. (floci a astimo) discussed on p. 27.

See under magni, maximi, pluris, plurimi, parvi, minoris, tantiquanti, tanti, quanti; nihili, assis; the ablative in money valuations; duplo; pretio, aere, momento, vita, contubernio; standard of valuation in the ablative; magno, parvo, minimo, quanto; nihilo, pro nihilo; carius, gravius, iuxta, pensius, vilius.

\section{Censere}

See under quanti; aere; summa; standard of valuation in the ablative; pro and the ablative; carius, graviter.

\section{Computare}

See under pretio; pro nihilo.

\section{Consulere}

See under boni.

\section{Dedicare}

See under quanti.

\section{Deprehendere}

See under nihili.

\section{Ducere}

Neither Plautus nor Terence seems to use ducere in expressions of valuation, but its occurrence in early Latin is attested by an example in Naevius (Th. de P. I 70 ) noctem nauco ducere.

For other examples see under magni, pluris, parvi, minoris, tanti; pensi; incomparabilis pretii, nullius momenti; pro nihilo, pro magno; in pretio, in lucro, in damno, in magnis ponderibus. 


\section{Esse}

Esse was doubtless one of the earliest verbs used in this construction, and it occurs frequently in all the periods represented by the extant literature.

See under magni, maioris, pluris, plurimi, parvi, minoris, tantiquanti, tanti, quanti; pensi; the genitive in definite valuation; mihili, nauci, sextantis; the ablative in definite valuation; pretio, momento; magno, quanto, vilissimo; the ablative with pro and in.

\section{Existimare}

This verb properly means to judge, consider, think, rather than value or rate (aestimare) and its use with a genitive of value is colloquial and comparatively rare. The examples usually cited are Plaut. Most. 76 satin abiit neque quod dixi flocci existumat? Capt. 682 dum ne ob malefacta peream, parvi existumo; Sulp. ap. Cic. Fam. iv. 5. 2 omnia minoris existimare; Nep. Cat. I. 2 magnique opera eius existimata est; Suet. Aug. 40 magni praeterea existimans .... incorruptum servare populum. To these may be added Plaut. Pers. 353 non ego omnis inimicitias pluris existumo quam; Cic. Fam. xiii. Io. 4 si me tanti facis, quanti et Varro existimat et ipse sentio; Sen. Ben. vi. 35.2 tanti existimat illum miserum esse ut ipse gratus sit; Plin. H.N. 35.94 Claudius pluris existumavit ... A Augusti imagines addere; Aug. Contr. Faust. xiv. I tanti devotiones eius existimare debemus, quanti sunt stomachantium vetularum; Quaest.v. 3 I magni extimantur (sic) haec ab hominibus; Sulp. Sev. Append. Ep. ii. 3 pudicitiam aut nullius praemii aut parvi existimat.

Existimare, moreover, is a very frequent variant of aestimare, especially in the letters of Cicero and of Seneca. It is also the reading of $B$, the fine MS of Lactantius belonging to the sixth or seventh century, in Div. inst. iii. 25. 16. In regard to Cicero's usage Schmalz, ZFGW, XXXV, 99, takes the position that wherever the MSS waver between aestimare and existimare construed with a genitive of value, aestimare is to be read, and this is, generally speaking, the tendency of recent editors. The question, however, may be seriously raised whether this continual ruling out of existimare in favor of aestimare is justifiable. The evidence of the MSS in the different passages which Schmalz discusses is certainly by no means conclusive. For example in M Iur. I6. 34 cuius ... . vita tanti existimata or aestimata est, existimata is the reading of the MSS and is retained by Halm in the Orelli and Baiter edition of 1854 , again in his edition of 1868 , and by Kayser, 1862 , though Halm, I878, Koch-Landgraf, г 885, Müller, I892, and Clark in the Oxford 
text, I905, read aestimata. In Leg. Agr. ii. I5. 40 minas non quanti volet existimabit, or aestimabit, Müller in his critical note gives existimabit as the reading of "omnes codices," and this is adopted by Zumpt and Kayser. Müller himself, however, Baiter, and Clark read aestimabit. In Att. i. 20. 2 nullam rem tanti existimassem, or aestimassem, Boot, Wesenberg, Tyrrell, and Purser following Lambinus, Bosius, and some of the MSS, read existimassem, though M has aestimassem, which is adopted by Kayser.

\section{Facere}

This is the favorite verb of rating in colloquial Latin, occurring frequently in Plautus, Terence, the Letters of Cicero, and other works containing a large element of the sermo cotidiamus. A good index of its usage is furnished by the statistics for Cicero, in whose writings only nine examples are found in the Speeches, and nine in the Philosophical Works, while in the Letters there are sixty. With expressions of worthlessness it is especially frequent. It is not, however, confined to the colloquial sphere. Besides the examples in Cicero's Speeches and Philosophical Writings referred to above, there are a few in Sallust and Livy, as well as a goodly number in the Digest and Church Fathers. Caesar does not use it in this construction.

For the combinations in which it is used and the authors in whose works it is found, see under magni, maximi, multi, pluris, plurimi, parvi, minoris, minimi, tanti-quanti, tanti, quanti; nihili, flocci, nauci, hettae, pili, terunci, assis dupondii; momenti, preti; aequi, boni; quanto; multum, nihil, plus.

\section{Finire}

See under tanti.

\section{Habere}

The first example of habere used as a verb of rating is found in Caecilius ( 249 R) tantam rem dibalare ut pro nilo habuerit. Another early example occurs in Lucilius (I I20 Marx) tantum habeas, tantum ipse sies tantique habearis.

For other examples see under magni, pluris, parvi, minimi, quanti, tanti; nauci; pensi; pretio; pro nihilo, pro nullo, pro magno, pro luto; in pretio.

\section{Indicare}

See under tanti, quanti. 
Licere

See under pluris, quanti.

\section{Pendere}

Pendere in expressions of valuation occurs frequently in comedy, not at all in Cicero's Speeches or Philosophical Works or in Caesar, apparently not in Cicero's Letters or in Livy, occasionally in Lucretius, Persius, Seneca, Tacitus, Gellius, Apuleius, Macrobius, and frequently in patristic Latin. The sermo cotidianus is its proper sphere but it not infrequently finds a place in graver discourse.

For the details of its usage see under magni, pluris, plurimi, parvi, minoris, tanti, quanti, nihili, flocci; pretio; standard of valuation in the ablative; pro nihilo.

\section{Pensitare}

See under magni.

\section{Ponderare}

See under momento.

\section{Putare}

Putare does not occur in Plautus in an expression of valuation; nor is it found in Terence in this construction, although there is an approach to it in Hecyra 799 meam erus esse operam deputat parvi pretii. In Catullus 23. 25 we find haec commoda . . . noli spernere nec putare parvi. Cicero uses it more frequently than Stegmann's article, Jahrb., CXLII (1890), 29 ff., would lead one to suppose.

For other examples see under magni, pluris, minoris, minimi, tanti, quanti; nullius momenti; nihili, nauci; the ablative in money valuations; pro nihilo.

\section{Reputare}

See under nihilo and pro nihilo. Cf. also Vulg. Act. I9. 27 magnae Dianae templum in nihilum reputabitur, where the Greek has $\epsilon i s$ oi $\theta \dot{t} \nu$

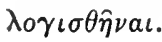

\section{Sumere}

See under pro magno.

\section{Supputare}

See under dupondii. 


\section{Tazare}

See under minore; tanti-quanti, tanti, quanti; the ablative in money valuations.

\section{Valere}

See under pluris, minoris, quanti; maiore, minimo; pro and the ablative in money valuations; multum. Cf. also Petron. Cen. 77 assem habeas, assem valeas. 


\section{INDEX}

Ablative with verbs of rating: in definite valuation, $3 \mathrm{I}-32$; in expressions of worthlessness, $35-36$; in indefinite valuation, $32-35$; origin of the construction, 31; with a preposition, $37-40$

Adverbs with verbs of rating, 41

acqui bonique faccre, 22

acre, 33

aeris minimi, 4

aestimare, 42

alga, 36

asse, 36

assis, 29

Attributive genitives of valuation, 9-10 auro, 37

Bennett, 3, 5, 7, 3I

boni consulere, acqui bonique facere, $21-22$

Bräunlich, 5

Brugmann, 5

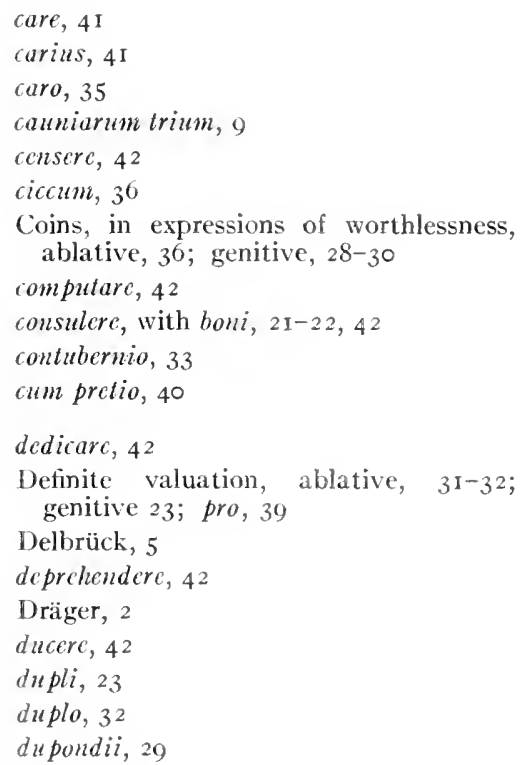

flocci, 26-27

floccum, 36

Genitive: in definite valuation. 23-24; in expressions of worthlessness, 24-30; in indefinite valuation, IO-2I; origin of use in expressions of value, I-IO

Gestures, 16, 30

gravitcr, $4 \mathrm{I}$

gravius, 41

lictlae, 28

huivs, 30

lnumiliter, $4 \mathrm{I}$

in damno, 40

in lucro, 40

in pondere, 40

in pretio, 40

Indefinite valuation, ablative, 32-35; cum, 40; genitive, ro-23; in, 40; pro, 39

iuxla, 4 I

Kühner, 2

Landgraf, 2

lapidibus oplimis, 37

levius, $4 \mathrm{I}$

Locative origin, theory of, I

latec, 37

Madvig, 3, I 7

magni, 10-I I

magno, 34

maiore, 34

maioris, II

malli, 25

maximi, 12

minimi, $\mathbf{1}_{5}$

minimo, 35

minore, 34

minoris, 15

momenti: levioris, with verb, 3; magni, with verb, 3, 4; maximi, with verb, 3 , with noun, 9; non ullizs, with verb, 3; 
mullius, with verb, 3, 4; parvi, with verb, 3 ; quanti, with verb, 3 ; tanti, with verb, 4

momento, 33

mominis (nullius), 4

Money valuation, ablative, 32; genitive,

23 ; pro, 39

multi, I 2

multum, 4 I

nauci, with noun, 9; with verb, 27-28

nauco, 36

nihil, 4 I

nihili, with noun, 9; with verb, $24-26$

nihilo, 35

mulli, 26

Origin of the ablative with verbs of rating, 3 I

Origin of the genitive of value, $I-8$

Partitive origin, theory of, $I-2,8$

parvi, I4

parvo, 34

pensi, 22

pensius, 4 I

pili, 28

pluma, 36

plure, 34

plurimi, I 3

pluris, I $2-\mathrm{I} 3$

plus, 4I

ponderis: alicuius, with verb, 4 ; gravioris, with verb, 4; maioris, with noun, 9; maximi, with verb, 3 ; nullius, with verb, 4

pretii (without epithet), 4

pretii: abiccti, with noun, 9; alicuius, with verb, 3 ; cuius, with verb, 4; eiusdem, with verb, 3,4 ; incomparabilis, with verb, 4; magni, with verb, 4, with noun 9 ; maioris, with noun, 9 ; maximi, with noun, 9; minimi, with verb, 3 , with noun, 9; multi, with noun, 9; nullizs, with verb, 4, with noun, 9; parvi, with verb, 3, 4, with noun, 9; pluris, with noun, 9; quantivis, with verb, 3 , with noun 9

pretio, 32

pro dente, 39 pro luto, 39

pro magno, 39

pro magno aere, 39

pro nihilo, 37-39

pro nullo, 39

pro oculo, 39

pro pretio, 39

Quality, genitive of, 2-6, 8-10

quanti, I9-2 I

quanto, 35

quantocumque, 35

quanto-tanto, 35

Reisig, I

Roby, I

semissis, with noun, Io, 29

sescunciae, with noun, 9,29

sestertio nummo, 36

sextantis, with noun, 9; with verb, 29

simpli, 59

Sloman, I

Sonnenschein, I

Standard of valuation in the ablative, 33

Stegmann, 2

summa, 33

tanti, 16-I9

tanti, with gesture, I6

tanti esse, 16-18

tanti-quanti, I 5-I6

tenuissime, 4 I

ierunci, 29

tressis, Io, 30

trioboli, , 0,30

Verbs of rating, $42-46$

vili, 35

vilissimo, 35

vilius, $4 \mathrm{I}$

vita, 33,37

Wackernagel, 5, 6-8

Wölfflin, 2, 28, 3 I

Worthlessness, expressions of, ablative, 35-36; genitive, 24-30; pro, 37 


\section{I FE.}

I was boin in London, Ontario, on October 16, 1869, and received my primary and secondary edncation in the public schools of that city. In the fall of $188 \%$ I entered the University of Toronto, where I took courses in elassical and modern langnages. I graduater with the degree of A. B. in 1891. For the two following years I was Classical Master in Whetham College, Vancouver, British Columbia.

My graduate courses in the Johns Hopkins University were in Latin. Greek and Roman Law. Since taking the degree of Doctor of Philosophy there, I have been Fellow in the American School of Classical Studies in Rome, Instructor in Latin in Rryn Mawr College. and Professor of Latin in the University of Chicago.

G. J. I. 
. 


$$
\text { - }
$$


UNi

A LIBRARY,

$$
\text { BETiLLEI }
$$

THIS BOOK IS DUE ON THE LAST DATE STAMPED BELOW

Books not returned on time are subject to a fine of $50 \mathrm{c}$ per volume after the thind day orerdue, increasing to $\$ 1.00$ per volume after the sixth day. Books not in demand may be renewed if application is made before expiration of loan period.

MAY : " 1909 


\section{Gaylord Eros}

Makors

syracuse. in.

PAT, 3BN, 21, 1908

Af

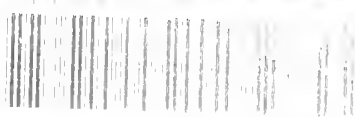

050

UNIVERSITY OF CALIFORNIA LIBRARY
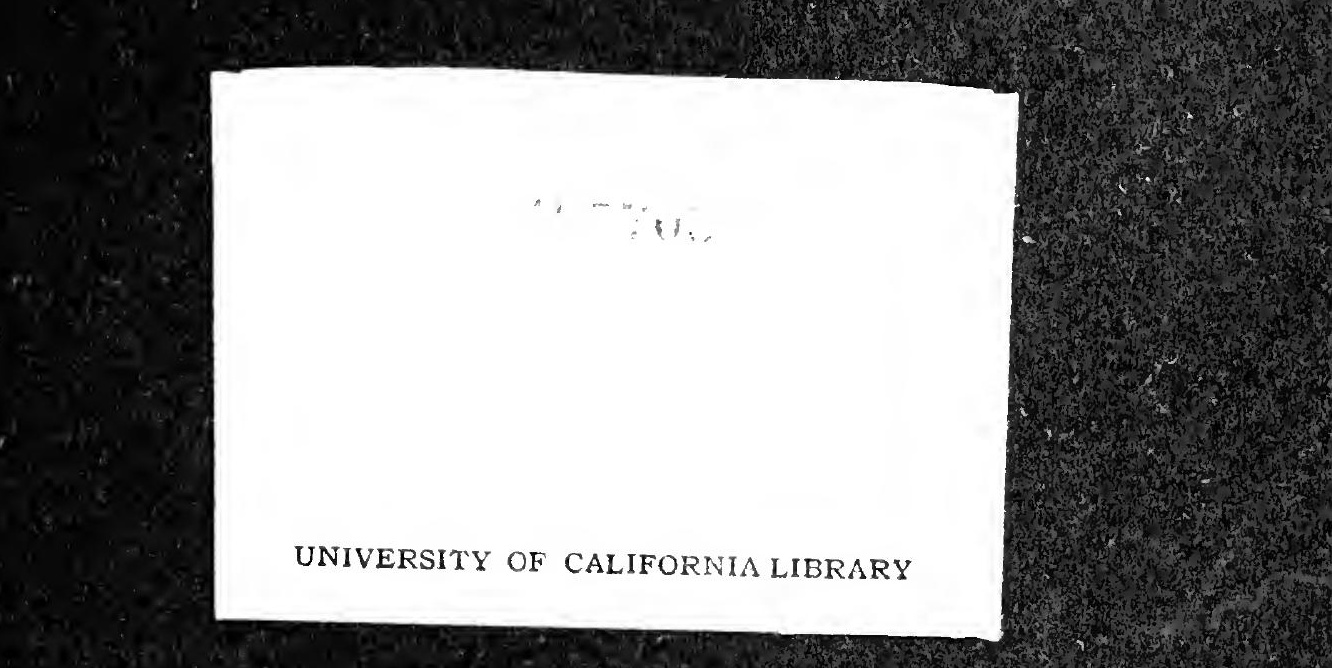
1) m. 1
of

2. hat

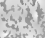
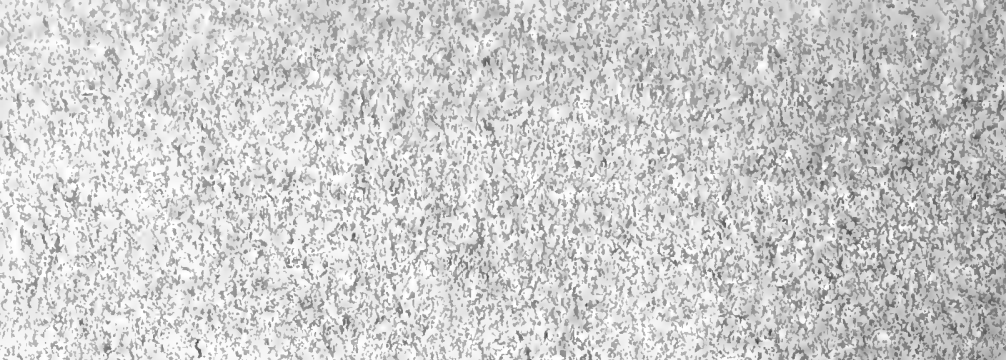

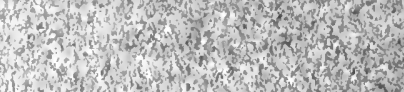

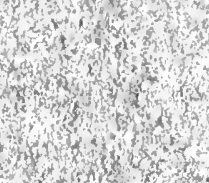

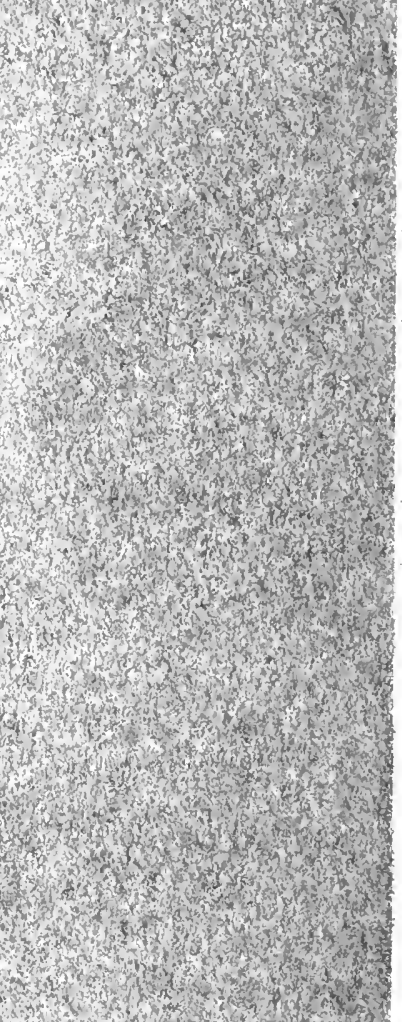

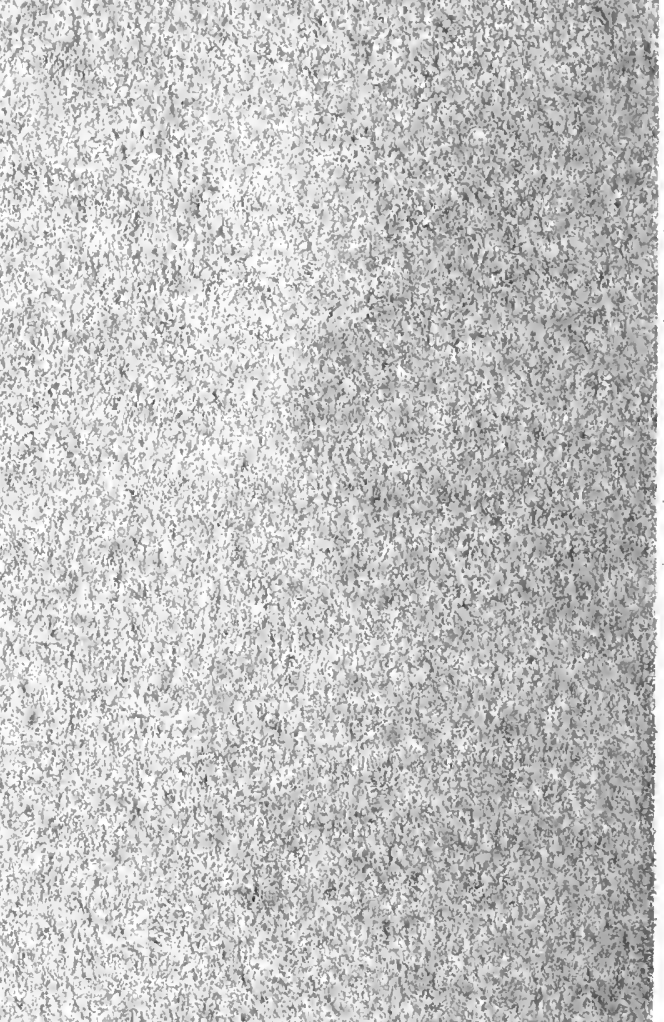
W.

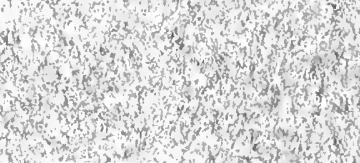

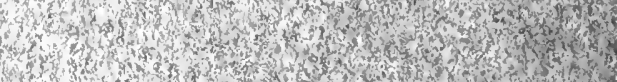
Hon

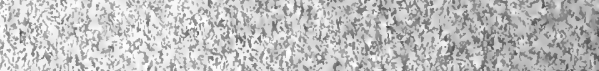

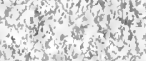
H.

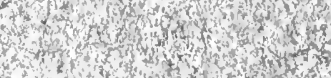

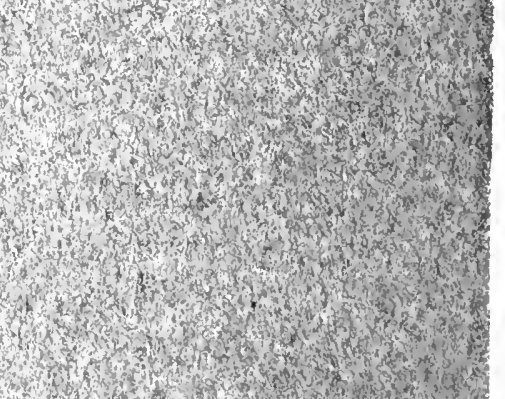

